University of Wollongong

Research Online

Faculty of Business - Papers (Archive)

Faculty of Business and Law

$1-1-2017$

Foreign exchange intervention in Asian countries: What determine the odds of success during the credit crisis?

Mei-Ching Chang

National Chengchi University

Sandy Suardi

University of Wollongong, ssuardi@uow.edu.au

Yuanchen Chang

National Chengchi University

Follow this and additional works at: https://ro.uow.edu.au/buspapers

Part of the Business Commons

Research Online is the open access institutional repository for the University of Wollongong. For further information contact the UOW Library: research-pubs@uow.edu.au 


\title{
Foreign exchange intervention in Asian countries: What determine the odds of success during the credit crisis?
}

\author{
Abstract \\ This paper investigates the factors that increase the odds of intervention success by Asian central banks \\ in the foreign exchange market from January 2005 to November 2013. The results show that leaning- \\ against-the-wind intervention strategies are effective in Indonesia, Malaysia, Philippines, Singapore, South \\ Korea, Taiwan, and Thailand, particularly to counter the pressure of appreciating domestic currency by \\ purchasing US dollar. We find that coordinated and first day interventions are associated with higher odds \\ of effective intervention. There is also evidence that central banks intervene to calm disorderly market.

\section{Disciplines \\ Business}

\section{Publication Details} \\ Chang, M., Suardi, S. \& Chang, Y. (2017). Foreign exchange intervention in Asian countries: What \\ determine the odds of success during the credit crisis?. International Review of Economics and Finance, \\ 51 370-390.
}




\title{
Foreign Exchange Intervention in Asian Countries: What Determine the Odds of Success during the Credit Crisis?
}

\author{
Mei-Ching Chang \\ Department of Finance \\ National Chengchi University \\ Sandy Suardi \\ School of Accounting, Economics and Finance \\ University of Wollongong \\ Yuanchen Chang* \\ Department of Finance \\ National Chengchi University
}

\begin{abstract}
This paper investigates the factors that increase the odds of intervention success by Asian central banks in the foreign exchange market from January 2005 to November 2013. The results show that leaning-against-the-wind intervention strategies are effective in Indonesia, Malaysia, Philippines, Singapore, South Korea, Taiwan, and Thailand, particularly to counter the pressure of appreciating domestic currency by purchasing US dollar. We find that coordinated and first day interventions are associated with higher odds of effective intervention. There is also evidence that central banks intervene to calm disorderly market.
\end{abstract}

Key words: Central bank intervention; Credit crisis; Asian currency; Leaning-against-the-wind

JEL codes: E58; F31

\footnotetext{
Corresponding author at: Department of Finance, National Chengchi University, No. 64, Sec. 2, ZhiNan Rd., Wenshan District, Taipei City 11605, Taiwan, ROC. Tel.: +886 $229393091 \times 81102$, E-mail: yccchang@nccu.edu.tw
} 


\title{
Foreign Exchange Intervention in Asian Countries: What
}

\section{Determine the Odds of Success during the Credit Crisis?}

\begin{abstract}
This paper investigates the factors that increase the odds of intervention success by Asian central banks in the foreign exchange market from January 2005 to November 2013. The results show that leaning-against-the-wind intervention strategies are effective in Indonesia, Malaysia, Philippines, Singapore, South Korea, Taiwan, and Thailand, particularly to counter the pressure of appreciating domestic currency by purchasing US dollar. We find that coordinated and first day interventions are associated with higher odds of effective intervention. There is also evidence that central banks intervene to calm disorderly market.
\end{abstract}

Key words: Central bank intervention; Credit crisis; Asian currency;

Leaning-against-the-wind

JEL codes: E58; F31

\footnotetext{
* Corresponding author at: Department of Finance, National Chengchi University, No. 64, Sec. 2, ZhiNan Rd., Wenshan District, Taipei City 11605, Taiwan, ROC. Tel.: +886 22939 3091x81102, E-mail: yccchang@nccu.edu.tw
} 


\section{Introduction}

The voluminous literature on foreign exchange interventions has traditionally focused on advanced economies (Dominguez and Frankel, 1990, Leahy, 1995, Dominguez, 1998, 2006, Dominguez et al, 2013, Chang and Taylor, 1998, Humpage, 1999, 2003, Baillie et al, 2000, Bordo et al, 2012a, 2012b, Ito, 2005, Ito and Yabu, 2007, Fatum and Hutchison, 2002, 2003, 2006, Kearns and Rigobon, 2005, Fatum, 2008, and Neely, 2011). Nevertheless, in recent years the empirical stylized facts of foreign exchange interventions have changed in several important ways. Major central banks in advanced economies, particularly those in the G7, have intervened less frequently post-1996. ${ }^{1}$ On the other hand, many central banks in emerging markets, especially in Asia, have experienced large balance sheet expansions through the accumulation of foreign reserves and accompanied by more frequent foreign exchange interventions. Cook and Yetman (2012) document that the asset expansions in Asian central banks' balance sheets have been caused by a build-up of foreign exchange reserves. ${ }^{2}$ Although we have witnessed a recent rising trend of central bank engagement in competitive exchange rate management in emerging markets, evidence of intervention efficacy remains sparse.

This paper is the first to demonstrate the use of Reuters' news reports as a proxy for Asian central bank interventions, providing a contribution to empirically determine whether such interventions are effective using data from January 2005 to November 2013. This sample period is chosen because there are extensive

\footnotetext{
${ }^{1}$ Neely (2011) highlights the mid-1990s as the start of the post-intervention era. Authorities of developed countries doubted of the efficacy of foreign exchange intervention operations and stopped intervening or intervened less frequently in the foreign exchange market. For example, the Bank of Canada stopped intervening in 1988, while the European Central Bank has intervened very rarely since 1999. In addition, central banks over times have turned to inflation targeting rather than exchange rate targeting as a framework for monetary policy.

${ }^{2}$ Foreign exchange reserves made up more than $80 \%$ of central bank assets for eight Asian countries, comprising China, Hong Kong, India, Malaysia, Philippines, Singapore, South Korea, and Thailand. While Indonesia may be the only exception, its foreign reserves have constituted more than half of its central bank assets since 2006.
} 
intervention reports on currency markets by Asian central banks that coincide with the global credit crisis and U.S. quantitative easing. International funds have rapidly flowed in and out of Asian countries, giving rise to large fluctuations of Asian currencies during that period. In addition, the stronger external drivers driven by prolonged low interest rates in developed economies combined with excess global liquidity arising from quantitative easing measures have amplified short-term portfolio flows into Asian economies seeking higher returns. The influx of capital flows into Asian economies inadvertently impact on the respective country exchange rates. This study seeks to study (1) whether central bank's foreign exchange interventions were successful in Asian countries during the period of unconventional monetary policy in advanced economies, for which large capital inflow has resulted in appreciation pressure on the respective countries currencies; (2) what factors determine the central bank to intervene in the foreign exchange market; and (3) what intervention strategies were found to increase the odds of successful intervention.

There is a large body of work that has focused on rationalizing the causes and consequences of foreign currency reserve build-up in emerging Asian economies especially since 1998 (Bird and Rajan 2003, Aizenman and Marion, 2003). These studies have concluded that Asia holds more than enough reserves as a financial safeguard, and that this sustained reserve build-up has been motivated by a desire to keep currencies from appreciating significantly. In an effort to shield the domestic financial system from volatile capital in- and outflows, many Asian economies central banks have massively accumulated reserves. ${ }^{3}$ In addition, during the global financial crisis, part of the large influx of international funds into Asia has been

3 The main reasons for holding reserves are the need to service government's foreign debt, to provide the option to intervene in the foreign exchange market for maintaining orderly market and to provide liquidity to banks in extreme situations. 
driven by the U.S. Federal Reserve's quantitative easing policy to stimulate the U.S. economy after the global credit crisis, which resulted in a long-term downward trend of the US dollar viz-á-viz Asian currencies. In the face of appreciation pressure on their currencies, several Asian central banks have frequently intervened in the foreign exchange market to stabilize their exchange rates with a view of promoting and maintaining their export competitiveness. This paper fills an important gap in the literature on foreign exchange intervention in Asian markets for reasons that (1) studies on Asian foreign exchange intervention is scarce due to intervention data paucity, and (2) the period that we examined coincides with unconventional monetary policy which has never occurred in the past and on that basis it presents an opportunity to study a plethora of Asian economies with different exchange rate systems.

This paper uses the analytical framework of Humpage (1999) who shows that the U.S. intervention against German Deutsche Mark and Japanese Yen has the ability to influence exchange rate movements under a weak leaning-against-the-wind criterion. ${ }^{4}$ This framework bodes well with the coordination channel of intervention in that intervention might be important in coordinating the expectations of market participants. Sarno and Taylor (2001), Taylor (2005), and Reitz and Taylor (2008) emphasizes the importance of this coordination channel in communicating the authorities' belief that the exchange rate is deviating substantially from its long-run value. In light of the appreciating Asian currencies against the US dollar recently, many authorities believe that this undue appreciation pressure does not reflect the true external value of their currencies, thus

\footnotetext{
${ }^{4}$ Humpage (1999) refers to the predictive power of intervention as forecast value, which are defined more elaborately in Section 4 in terms of exchange rate movements.
} 
potentially hurting their exports. ${ }^{5}$

Following Fatum and Hutchison (2002), we use news reports on Asian central banks' interventions to analyze the effectiveness of exchange rate management by central banks in India, Indonesia, Malaysia, Philippines, Singapore, South Korea, Taiwan, and Thailand. The method of Humpage (1999) also permits the success of intervention operations, as proxied via these news reports to be judged within a probabilistic framework. This probabilistic framework squares well with the element of market psychology in the operation of the coordination channel, because it relies on traders recognizing the authorities' intervention operations as a coordinating effort implied by such intervention news. Evidence, supporting the coordination channel, leads to the probability of intervention success to be represented as an increasing function of the degree of intervention.

Our results can be summarized as follows. First, there is a strong correlation between Reuters' intervention reports and the changes of exchange rates for all eight Asian countries. In particular, firm intervention reports in the period post-2008 appeared to have increased following the adoption of unconventional monetary policy in advanced economies. Second, there is evidence that most Asian countries, with the exception of Indonesia and India, are purchasing USD as part of their intervention strategies to counter the pressure of rising external value of domestic currency caused by unconventional monetary policy in advanced economies. ${ }^{6}$ It was found that their learning-against-the-wind intervention policy was successful in

\footnotetext{
${ }^{5}$ There is also the traditional portfolio balance approach to exchange rate determination. The portfolio-balance channel explores the impact of changes in relative supply of domestic (change in the quantity of publicly held government debt) and foreign assets due to the intervention operations (Dominguez and Frankel, 1993). This approach suffers from data paucity; the data on domestic and foreign assets are, more often than not, available at annual frequency thus restricting the analysis of exchange rate intervention at the daily level.

${ }^{6}$ Most trades around the world are invoiced in US dollar. Table A1 of Casas et al. (2016) shows that in all of the countries examined in this study, which are reported in Table A1, their trades are invoiced in US dollar. For this reason our analysis is restricted to bilateral exchange rates vis-à-vis the US dollar.
} 
reducing the speed with which exchange rates are appreciating. Third, when controlling for factors that explain the effectiveness of intervention by Asian central banks, we find that the odds of successful intervention are both statistically and economically influenced by the presence of joint/coordinated interventions and first-day interventions. Official statement of support also wields a significant effect on increasing the success of intervention. Finally, there is evidence to suggest that central banks intervene during the credit crisis period to calm disorderly market. It is important to recognize that while the evidence presented here is built on the premise of the accuracy of Reuters news reports of actual interventions, we can be confident that given the conservative estimates of newswire reports as a proxy for actual interventions, these results may underestimate the strength of the underlying relationships between variables.

The remainder of the paper is organized as follows. Section 2 provides a literature review focusing on intervention channels, studies conducted on both developed and developing countries, and the recent intervention experience of seven Asian economies examined in this study during unconventional monetary policy in advanced economies. Section 3 describes the data. Section 4 discusses the methodology and provides the empirical results. Section 5 concludes and discusses the implications of our results.

\section{Literature Review}

\subsection{Intervention channels}

Official intervention in the foreign exchange market occurs when central bank authorities buy or sell the US dollar, normally against their own currencies, in order to affect the level of their local exchange rate. There are three channels through 
which official intervention might affect the foreign exchange market indirectly: the portfolio balance channel, the signaling channel, and the coordination channel.

The portfolio balance channel alludes to sterilized intervention changing the relative supplies of bonds denominated in different currencies. Given that bonds from different countries are imperfect substitutes and that traders' demand for bonds from a particular country is determined by their given rate of return, then the relative returns on certain bonds depend on the relative quantities of those bonds to other currency-denominated bonds. Researchers, however, are skeptical that the portfolio balance channel can explain the effectiveness of interventions, because interventions are usually way too small to significantly change the relative quantities of bonds (Humpage, 1999). Nevertheless, Galati and Melick (2002) argue that the portfolio channel may be more relevant for emerging markets because they are more likely to have large reserve portfolios relative to local foreign exchange market turnover or the stock of domestic bonds outstanding. Moreover, given that the degree of substitutability between emerging market currency debt and foreign currency debt is generally smaller - as reflected in higher risk premia on the former - the portfolio balance effect may also be stronger in these countries. For this reason, while it may seem appropriate to study the effectiveness of foreign exchange intervention within the framework of portfolio balance channel, data paucity and the low frequency of available data tend to render the analysis restrictive.

The signaling channel suggests that official intervention signals information about future monetary policy. The literature on intervention has not been favourable toward this channel. Using bivariate vector autoregressions and Granger causality tests, Lewis (1995) has examined whether intervention helps predict future changes in monetary policy in the US context. The study reports a mixed picture of the 
signaling story and finds a circular relationship between intervention and future monetary policy. Kaminsky and Lewis (1996) have also reported similar results, which indicate that the US intervention provided a signal to future changes in interbank rates and monetary aggregates, but sometimes in the opposite direction of that predicted by the conventional signaling hypothesis. On the other hand, Fatum and Hutchison (1999) fail to find that intervention exerts any effect on federal funds future rates. More importantly, the plausibility of the signaling story is in doubt, given that both monetary policy and exchange rate policy are generally managed by two different institutions in an economy. For example, the U.S. Treasury is responsible for the value of the USD and it is unlikely that its intervention signal would communicate anticipated monetary policy decided by the FOMC. It has been argued that the signaling channel is likely to be weaker in emerging market countries since central banks in these economies have a shorter history of institutional and policy credibility than their counterparts in developed economies (BIS, 2005).

The coordination channel, which is the most plausible channel of the three, suggests that intervention might be important in coordinating the expectations of market participants. This channel has received increasingly greater importance in the literature, because intervention communicates the authorities' belief about the exchange rate being misaligned from its long-run value. During such periods, individual traders are subject to greater risk if they invest capital in hopes of a return to the long-run equilibrium even though the exchange rate can persist to deviate from its long-run equilibrium level for an extended time period. Be that as it may, foreign exchange intervention can facilitate the convergence in the expectations of market participants and lead traders so as to align the exchange rate closer to its 
long-run equilibrium. It is this channel that we draw upon in this study for assessing the effectiveness of foreign exchange intervention.

\subsection{Developed and developing markets}

Over the years, there have been radical changes in the conduct of foreign exchange intervention. The U.S. monetary authorities used foreign exchange intervention to counter disorderly market conditions in 1980, although interventions became less frequent by the late-1990. Empirical works on the effectiveness of intervention have produced very mixed results and generally rely on data from developed countries, specifically the G7 countries (Dominguez and Frankel, 1990, Dominguez, 1998, Humpage, 1999, Fatum and Hutchison, 2002, 2003, 2006, Kearns and Rigobon, 2005). Dominguez and Frankel (1990) show that central bank interventions in Germany and the U.S. are effective in influencing exchange rate volatilities. Dominguez (1998) also presents that interventions by the U.S., Germany, and Japan tend to increase exchange rate volatilities during the 1977-1994 period. Humpage (1999) notes that intervention possesses some forecast value when the U.S. Treasury undertakes a weak leaning-against-the-wind policy.

The study of Fatum and Hutchison (2002) is the closest to ours in the sense that they utilize news reports from the Wall Street Journal to investigate the effects of intervention news on the Euro. Using four different categories of intervention news of the European Central Bank (ECB), they find that official statements denying ECB intervention or news that question the efficacy of intervention do have a significant and negative impact on the value of the Euro. On the other hand, firm reports of intervention, as well as rumors and speculation of intervention in support of the Euro lead to short-term Euro appreciation. Fatum and Hutchison $(2003,2006,2010)$ rely on a non-parametric sign test and a matched-sample test to document strong 
evidence that intervention by the Bank of Japan systemically affects its short-run exchange rate. Finally, Kearns and Rigobon (2005) show that interventions by the Reserve Bank of Australia and the Bank of Japan have significant effects on the Australian dollar and Japanese Yen.

The effectiveness of foreign exchange interventions has also been examined using intraday data. Fischer and Zurlinden (1999) highlight the difficulties of interpreting the regression results when intervention exchange rates are not available and the timing of the intervention usually falls within the interval of the exchange rate change. Using a new data set of foreign exchange transactions of the Swiss National Bank (SNB) for the period 1986-1994, they were able to study the intraday effects of interventions arising from informational differences between interventions and SNB customer transactions. Interventions reveal central bank discontent with exchange rate conditions and may signal news about future monetary policy while customer transactions do not. They were able to show that interventions unlike customer transactions affect expectations and exchange rates. In a related study, Payne and Vitale (2003) extended the analysis of Fischer and Zurlinden (1999) by matching the tick-by-tick transactions data with indicative intraday exchange rate quotes and news wire reports of exchange rate interventions. Their event study shows that intervention wields the largest impact when the SNB moves with-the-market and when there are concerted interventions with the other central banks. Burkhard and Fischer (2009) use high-frequency data and demonstrate that the SNB sterilised intervention references depreciated the domestic currency for several hours when short-term interest rates reach the zero bound. More recently, Pasquariello (2010) proposes a novel theory of the impact of sterilized spot interventions on the microstructure of currency markets and their liquidity. The theory specifically explores the manner by which potential (and often ignored) trade-off between policy goals and costs (or profits) may affect 
the impact of central bank interventions on exchange rate dynamics and on the liquidity of the forex market.

In contrast to the literature of foreign exchange intervention in developed economies, tests of the effectiveness of interventions in emerging markets are limited (Tapia and Tokman, 2004, Guimaraes and Karacadag, 2004, Disyatat and Galati, 2007, Bernanke, 2010, Chen, 2011, Domaç and Mendoza, 2004, Hua and Gau, 2006, Rincon and Toro, 2011, Menkhoff, 2013). Much of the literature on foreign exchange intervention in emerging markets has featured markets in the western hemisphere. Tapia and Tokman (2004) find that interventions by the Central Bank of Chile in the foreign exchange market affect both the level and volatility of the Chilean Peso during the Asian and Argentinian crises. Guimaraes and Karacadag (2004) use a modified generalized autoregressive conditional heteroskedasticity (GARCH) model to show that sales of USD intervention increases volatility both in the short run and long run and have a significant effect on the Mexican Peso, although purchases do not exert any effect. Domaç and Mendoza (2004) show that central banks in Mexico and Turkey can effectively influence the directions of their currencies. Rincon and Toro (2011) examine the efficacy of intervention when combined with capital controls in Colombia during the period 1993 to 2010, presenting that their simultaneous use tend to support intervention effectiveness by augmenting the exchange rate trend without increasing volatility.

Intervention studies in Asia are more limited to the case of India. Pattanaik and Sahoo (2001) examine the exchange rate policy in India for the period 1995-2003 under the objectives of stabilizing the exchange rate and keeping market conditions orderly. However, the assessment of intervention effectiveness is marred by the fact that these two goals are also achieved via monetary policy and capital controls. The 
intervention reaction function reveals that India's central bank reacts to volatility in the foreign exchange market but not to misalignments. Goral and Arora (2010), using intervention data from the Reserve Bank of India, show that interventions are effective in reducing volatilities of the Indian Rupee. As is clear from the limited number of studies on Asian foreign exchange intervention, our paper fills a very important gap in the literature by using Reuters' news reports to study the efficacy of intervention in eight economies.

\subsection{Newswire reports on foreign exchange interventions}

Reuters news reports have been employed in research on foreign exchange interventions for a number of reasons. Reuters news reports permit researchers to employ a narrow reaction window in minutes rather than in hours (Goodhart and Hesse, 1993) and days (Fatum and Hutchison, 2003). These news reports when used with intra-daily data enable researchers to test the signaling hypothesis (Dominguez, 2003; Goodhart and Hesse, 1993), and to determine the effectiveness of interventions in reducing exchange rate volatility (Chang and Taylor, 1998). But how accurate are the Reuters news reports?

Fischer (2006) studies the qualitative accuracy of the Reuters news reports for exchange rate interventions. He alludes to uncertainties in the properties and usage of these news reports based on (1) the lack of consensus among empirical researchers about the length of time between Reuters intervention announcement and the time stamp of actual central bank intervention, (2) the reporting of the intervention amount and the markets that the central bank intervenes ${ }^{7}$, and (3) the filtering rule of the news reports and their updates; Chang and Taylor (1998)

\footnotetext{
${ }^{7}$ Fischer (2006) only examines the Swiss National Bank exchange rate intervention data and find that Reuters does not always mention in which market the SNB intervenes and never its intervention volume.
} 
exclude announcements two hours after the first announcement while Sapp (2002) excludes reports in the first two hours. Using the Swiss National Bank spot transactions data, Fischer identifies that there are only six days where Reuters failed to report an intervention when the SNB did intervene, but there were no cases of false reporting (i.e. Reuters reported an intervention when there was no actual intervention). Based on the statistical properties of SNB intervention transactions and reported interventions, Fischer (2006) finds that the average number, the maximum, the minimum and standard deviation of transactions reported per day are substantially lower for Reuters than the actual interventions. Furthermore, there is low correlation (ranging from 0.21 to 0.33 ) between reported and actual interventions suggesting that newswire reports for Swiss interventions may not be accurate. $^{8}$

While the accuracy of Reuters reports for intervention studies is questionable, one could either totally disregard the validity of these Reuters news reports as a proxy for actual interventions or re-consider their usage but with caution, to the extent that Reuters news archives provide some information, though limited as they may be, about foreign exchange interventions particularly in an environment where no data on foreign exchange interventions are available such as the case in this study. Although information conveyed in these reports may not closely and fully capture actual interventions that took place, and if we were to believe Fischer's (2006) results are representative of all newswire reports for other countries central bank interventions, we can be assured at the very least that that these news reports, which

\footnotetext{
${ }^{8}$ More recently, researchers have considered determinants of false reporting in newswire reports caused by jumps in exchange rates and the induced effect of a transparent central bank intervention policy on market rumours which depends on oral interventions that are targeted at informing the market about the authorties' viewpoint of the level or volatility of exchange rates (Gnabo et al., 2009). $\mathrm{Be}$ that as it may, the percentage of false reporting is very low, only about $6 \%$ in the case of Bank of Japan interventions.
} 
provide an underestimate of actual interventions statistics, are conservative estimates of actual interventions. This is the position that we take in this study, which leads us to use Reuters' news reports to proxy for intervention activities in the eight Asian economies.

\subsection{Recent foreign exchange intervention experience in eight Asian countries}

We provide a brief overview of the foreign exchange intervention practices in eight Asian countries in recent years following the 2008 global financial crisis (GFC). The discussion below is largely taken from the working papers of the Bank of international settlement $(2005,2013)$ which focus on the motives, techniques and implications of foreign exchange intervention in emerging markets, particularly changes in the motives and strategy behind the interventions following the 2008 global financial crisis. Generally, intervention is viewed as an instrument that could potentially curb forex volatility and support market functioning. While sterilization occurred in several of the interventions, data paucity on central banks' balance sheet does not permit inference that all bank balance sheet expansion can be attributed to foreign exchange purchases.

\section{Indonesia}

Following the free floating of the Indonesian exchange rate in August 1997, foreign exchange intervention has been used to stabilise rupiah volatility during rapid depreciations associated with excess liquidity. The BIS (2005) reported that for the period 1997-2004 foreign exchange market intervention is effective in addressing unwarranted exchange rate movements stemming from temporary shocks. Maintaining exchange rate stability is deemed an integral part of an overall monetary and macroprudential policy mix designed to achieve price stability, economic growth, and monetary and financial system stability (BIS, 2013). This is especially so since 
the onset of 2008 global crisis where volatile capital flows, increasing risk appetite among global investors, and news on the progress of crisis resolution in the advanced economies have increased exchange rate volatility beyond the fundamental.

The Bank Indonesia intervenes mainly through spot transactions, which dominate the domestic foreign exchange market. Apart from direct intervention, Bank Indonesia has issued regulations which limit transactions by non-residents and net open positions, and by conducting both indirect (off-site) and direct (on-site) supervision of market participants. The intervention is conducted through agent banks to buy and sell foreign currency (mostly US dollars) depending on excess supply or demand conditions in the market, and it is aimed to smooth out the volatility of exchange rate movements along the chosen fundamental path. The conduct of foreign exchange intervention is integrated with domestic-currency monetary operations so that any impact on domestic liquidity is managed and is consistent with supporting the interest rate policy (i.e. sterilized intervention).

\section{Thailand}

Since July 1997 Thailand has adopted a managed-float exchange rate regime. The Bank of Thailand intervenes in the foreign exchange market to curb short-term excess volatility of the exchange rates and to maintain regional competitiveness, while ensuring that the exchange rate is aligned with fundamentals in the medium and long run. Shorter-term exchange rate fluctuations are used as an early warning indicator to help signal circumstances where there might be misalignment or destabilising market activities. Post 1997 Asian financial crisis, the Bank for a while accumulated foreign exchange reserves as a strong stock of reserves, which helps to minimize external vulnerability and increase confidence in the economy amongst foreign investors which, in turn, promotes a sound and stable currency. However, in recent years, the 
Bank's objectives focused more on discouraging sharp capital inflows from core economies during periods of unconventional monetary policy, and on maintaining external competitiveness. From 2006 until early 2008, the BOT imposed the Unremunerated Reserve Requirement (URR) on short-term capital inflows. Financial institutions were required to withhold $30 \%$ of foreign currency bought or exchanged for the Thai Baht (THB), though transactions related to trades in goods and services. Since 2010 the Bank started relaxing regulations in order to encourage capital outflows and to restore the balance between capital inflows and outflows in the market, creating natural counterflows while helping to promote outward direct investment (ODI) and encouraging Thai investment abroad.

The Bank employs actual intervention but does not announce any FX operations beforehand. ${ }^{9}$ The Bank intervenes in the foreign exchange market mainly via outright spot transactions by buying/selling Thai baht against US dollar, the currency most widely traded. The Bank intervene in the interbank FX market both onshore and offshore, and using designated agent banks in order to maintain anonymity. Foreign exchange swap transactions are sometimes used in conjunction with outright intervention to influence liquidity conditions in the offshore market in order to make it more costly to fund speculative positions. In addition, the bank is committed to the inflation targeting framework in which the 14-day repurchase rate is used as the operating target. Therefore, sterilisation is part of the appropriate management of liquidity in the money market. Like many other central banks' practice in Asia, data on foreign exchange market intervention are not published as the Bank is concerned that releasing intervention-related data for a small domestic foreign exchange market

\footnotetext{
9 If the country's current and expected fundamentals are in line with suspected intervention, expectations could be shaped easily. Otherwise, such a tack might pose risks or create doubt in the market.
} 
that is not adequately liquid could harm the economy, and the destabilising effect could limit the effectiveness of the intervention.

\section{South Korea}

After the Asian financial crisis, South Korea changed to a floating exchange rate regime in December 1997. Under the new exchange rate regime, the emphasis is to attain foreign exchange market stabilization through alleviating excessive short-term exchange rate volatility. Both the Ministry of Finance and Economy (MOFE) and the Bank of Korea (BOK) function as the exchange rate administrative body. ${ }^{10}$ The BOK intervenes in the foreign exchange market to mitigate short-term exchange rate volatility, to stabilise the foreign exchange market, to pre-empt speculative attacks, and to acquire foreign reserves, rather than to maintain a certain exchange rate target. It is also the case that the Korean foreign exchange authorities play the role of market maker through intervention by supplying sufficient liquidity thus filling the gaps between bids and offers in the market. Like Thailand, post Asian financial crisis, intervention was, unusually, utilised to increase international reserves in order to enhance Korea's credit rating and to avoid the possibility of another crisis. However, the exchange rate and its volatility have shown sharp increases during the global financial crisis in 2008 and the European sovereign debt crisis in 2010 and 2011 contrary to the moderate appreciation in the mid-2000 decade. In periods of crisis, the Bank also intervened to alleviate the foreign exchange funding shortages of banks, which have experienced severe dollar shortages. The foreign exchange funding shortage puts depreciatory pressure on the Korean won and increases exchange rate volatility.

\footnotetext{
${ }^{10}$ However, the BOK, as the central bank, holds and manages the nation's international reserves, composed of the foreign exchange stabilisation fund and the BOK's own reserves, and is also in charge of implementing foreign exchange market intervention operations in consultation with the MOFE.
} 
Both verbal intervention by the authorities and real intervention in the spot market are used. Verbal intervention facilitates foreign exchange market stability beforehand or forewarns speculative forces of the authorities' concerns and intention related to exchange rate movements. Spot market intervention is usually preferred when the objective is to contain exchange rate volatility, while swap market intervention is employed when the aim is to provide dollar liquidity in the market. The strength and nature of the external shock, the movements of market indices, market sentiments and the volume of funds available, are all taken into account in making the discretionary decision. The BOK monitors exchange rate developments and the foreign exchange market situation on a real-time basis through incessant contacts with dealers and analysis of various reports from the banks. Korea occasionally sterilises changes in its domestic money supply brought about by foreign exchange market intervention. Korean authorities have maintained secrecy regarding foreign exchange intervention. This is to avoid superfluous controversy over the validity of intervention, to induce autonomous exchange rate adjustments through market participants' trading, and to prevent speculative forces from benefiting from the relevant information.

\section{India}

India adopted a market-determined exchange rate system in March 1993. Within this system, the Reserve Bank of India intervenes occasionally to maintain orderly market conditions by curbing excess volatility in exchange rates. India relies on large capital inflow to fund its current account deficit. However, the capital flows are proven large and lumpy thus making the Indian foreign exchange market particularly susceptible to bouts of volatility. Depending on the prevailing market conditions, the Bank intervenes in both the spot and forward markets, directly and indirectly. The ability to intervene in either market gives the Bank's intervention operations greater 
capacity to modulate domestic rupee liquidity conditions in consonance with the prevailing monetary policy stance. The indirect approach has the advantage of maintaining the confidentiality of the intervention operations, thereby enhancing their effectiveness. In 2006-08, the Bank intervened in the market by buying US dollars following large and lumpy capital inflows far in excess of the economy's absorptive capacity (BIS, 2013). The rupee, however, came under sharp depreciation pressure in the aftermath the of global financial crisis, especially immediately following the Lehman collapse in September 2008, and this forced the Bank to sell US dollars in an attempt to restore orderliness in the market. In 2009-11, there was very limited scale of intervention operations taken by the Bank as domestic foreign exchange markets generally remained stable with the rupee exhibiting range-bound movement (see Figure $1 \mathrm{a}$ ). Intervention in the foreign exchange market is sometimes sterilized.

\section{Malaysia}

After pegging the exchange rate to the US dollar following the 1998 Asian financial crisis, Malaysia moved to a managed float exchange rate regime in July 2005. The exchange rate is referenced against a basket of currencies of the country's major trade partners and it is allowed to move according to market forces. The central bank intervenes to maintain orderly foreign exchange market conditions with a view to avoiding extreme movements in the domestic exchange rate that could destabilise the real economy. Over the years, foreign exchange interventions have become much less frequent. In recent years, the Bank has focused more on addressing periods of market dysfunction. Experience has shown that portfolio flows are the main factor influencing ringgit volatility, given that such flows are often sizeable, short-term and sensitive to market news. When inflows or outflows have reached extreme levels, the Bank has intervened with the aim of mitigating volatility, 
maintaining orderly market functioning and reducing any destabilising effects on the real economy. In all cases, the decision to intervene has hinged on whether the financial markets are judged capable of intermediating these excessive flows.

\section{Singapore}

In contrast to other countries, Singapore has used the exchange rate rather than the interest rate as the instrument of monetary policy. The choice of the exchange rate is predicated on the Singapore economy's small size and its high degree of openness to trade and capital flows. In particular, the economy's openness means that the exchange rate bears a stable and predictable relationship to price stability as the final target of policy over the medium-term. More importantly, the exchange rate is relatively controllable through direct intervention in the foreign exchange markets. An exchange-rate-based monetary policy thus allows the government to retain greater control over macroeconomic outcomes such as output growth and price stability.

Singapore operates the basket, band and crawl (BBC) exchange rate system. The Singapore dollar is managed against a basket of currencies of its major trading partners (also known as the Singapore dollar nominal effective exchange rate or S\$NEER). The trade-weighted exchange rate is allowed to fluctuate within a policy band, which minimises the need for constant foreign exchange interventions, in contrast to a system based on a hard currency peg. The slope of the exchange rate policy band is reviewed regularly to ensure that it remains consistent with the economy's underlying fundamentals and to avoid misalignment. This is the crawl feature which is incorporated in the band. The slope of the policy band, as well as the level at which it is centred, is not disclosed.

Intervention takes place when the S\$NEER reaches the edge of the policy band on either side, or when there is undue volatility or speculation in the Singapore dollar. 
The Monetary Authority of Singapore (MAS) will intervene in the foreign exchange market using spot or forward transactions through primary dealers (PDs). It may also intervene before the band is reached, or allow the S\$NEER to breach the band before intervening. During the global financial crisis, MAS eased its policy, adopting a zero per cent appreciation of S\$NEER policy band, amidst expectations of moderating inflationary pressures and the risk of further deterioration in the external environment. The policy band was subsequently re-centred downwards in 2009. Singapore, like other emerging Asian economies, has to tackle the consequences of sustained capital inflows following the adoption of unusual monetary policies in developed economies. MAS has not had to undertake any capital flow management measures in its conduct of monetary policy.

\section{Philippines}

The Bangko Sentral ng Pilipinas (BSP) has adopted a floating exchange rate regime in which exchange rates are determined by the interplay of supply and demand factors in the foreign exchange market. Intervention by the BSP is driven by objectives to maintain monetary stability, to curb excessive exchange market speculation, and to discourage sharp capital inflows and outflows (BIS, 2013). The recent surge in foreign exchange inflows into the Philippines has allowed BSP to build up its international reserves, which help to insulate the economy against external shocks. Notwithstanding that, structural flows continue to be the dominant source of foreign exchange with the largest share coming from the export sector followed by remittances from overseas Filipinos and receipts from business process outsourcing services.

Foreign exchange trading is conducted through the Philippine Dealing System (PDS). The direct market participants include the member banks of the Bankers 
Association of the Philippines (BAP) and the BSP. Electronic trading is conducted through the Philippine Dealing and Exchange Corporation (PDEx), which was designated by the BAP as the official service provider for USD/PHP spot trading. BSP never pre-announces its foreign exchange interventions. Its decisions to intervene may be based on current developments or may call for pre-emptive action before the markets react to developing situations. It intervenes in both the spot and forward FX markets, and it also occasionally uses derivatives. BIS (2013) reports that for the 2005-2012 period interventions have been successful at limiting exchange rate volatility. Besides accumulating international reserves BSP sterilises the associated potential inflationary impact of intervention in recent years. There has been a decline in the extent of sterilisation between the 1994-2001 period and the 2002-2010 period, which may indicate that the policy shift from monetary aggregate targeting to inflation targeting has given the BSP greater flexibility to achieve price stability without relying so much on sterilising excessive foreign exchange inflows.

\section{Taiwan}

Taiwan adopts a managed floating exchange rate regime and market forces have been permitted to affect the movements of the new Taiwan dollar since 1987. The Central Bank of the Republic of China (Taiwan), known as CBC, regularly intervenes in the foreign exchange market to smooth out the day-to-day excess fluctuations. Taiwan's currency is one of the steadiest across emerging markets even when it has a material current account surplus. There were reports that the $\mathrm{CBC}$ engaged in end-of-day intervention by setting the closing exchange rate at the last half-hour of currency trading in Taiwan ${ }^{11}$. CBC denied this end-of-day intervention and claimed that they intervene only when the market is disrupted by seasonal or irregular factors.

\footnotetext{
${ }^{11}$ Bloomberg news, “U.S. Sheds Light on Taiwan's Day-End Currency Intervention”, Oct/20/2015.
} 
In addition, $\mathrm{CBC}$ also uses moral suasion to affect the level of new Taiwan dollar and reduce the cost and visibility of exchange-rate management.

\section{Data}

This paper focuses on eight economies in Asia: India, Indonesia, Malaysia, Philippines, Singapore, South Korea, Taiwan, and Thailand. Our sample period covers January 2005 to November 2013. Daily exchange rate data are obtained from Bloomberg. The data are the composite rates by all banks offering traded prices to Bloomberg. We retrieved Taiwan's exchange rates (TWD) data using the opening and closing rates from Taipei Forex. The opening and closing exchange rates are defined for Hong Kong trading hours of 8:00 a.m. and 4:59 p.m., respectively. The same trading hours are employed for Indonesia, Malaysia, Philippines, Singapore, South Korea, and Thailand. In addition, we obtain India's quotes for Mumbai's trading hours from 9:00 a.m. to 4:59 p.m. We see that Asian countries exchange rates follow a similar pattern in that they generally appreciated relative to the US dollar, at times rapidly, until March 2008, depreciated very sharply until March 2009, and then appreciated gradually after the implementation of quantitative easing by the U.S. Federal Reserve until about 2013. In the case of India and Indonesia, the two countries' currencies experienced steep depreciation starting mid- 2011.

We use Reuters' news reports to extract information about central bank interventions in the foreign exchange market. These news reports consist of the date and time of a reported intervention. Our classifications of news reports are similar to that of Fatum and Hutchison (2002). Intervention news reports are classified as firm, suspected, supported, and neutral. A report is classified as a firm report when the news clearly state that the central bank intervened in the currency markets. This is synonymous with category D of Fatum and Hutchison (2002). A report is classified 
as a suspected report when the news cast doubt on official intervention in the foreign exchange market. This is synonymous with category A of Fatum and Hutchison (2002). A report is classified as a supported report when central bank or government officials provide statements that show support for intervention in the currency market (including suggestions that intervention is a possibility). This is equivalent to category B of Fatum and Hutchison (2002). A report is classified as a neutral report when central bank or government officials express neutral opinion on intervention activities. Firm reports are more certain on central banks' intervention activities and suspected reports are possible interventions with doubt. These two categories of reports specifically distinguish intervention in the buying and selling of US dollars.

The supported and neutral categories are news reports of central bank or government officials' verbal interventions on the foreign exchange market, and they do not highlight the difference in the intervention. Table A1 in the Appendix provides examples of the news reports and their categories.

\section{- Table 1 about here -}

Table 1 presents the distribution of intervention reports of the eight Asian countries categorized into firm, suspected, supported, and neutral reports. Panel (a) shows the number of intervention reports in two sub-sample periods. The first sample period (2005-2007) has a significantly fewer number of reports for firm and suspected reports than that in the second sample period (2008-2013). The second sample period coincides with the subprime crisis, which led to the introduction of the quantitative easing policy adopted by the US Federal Reserve. The fall in U.S. interest rates has brought about huge swings in capital flows to emerging market economies (EMEs) which have led many countries to re-examine their foreign 
exchange market intervention strategies. Quite unlike their experiences in the mid-2000s, some Asian countries found themselves having to intervene against strong appreciation pressures. It is not surprising, therefore, that the majority of intervention reports happened in this period. Panel (b) shows the number of days for which news on intervention is reported in the Asian countries. There are more intervention reports for Taiwan, South Korea, and Indonesia. We see that central banks in these countries intervened heavily in the foreign exchange market during the second sample period and the number of days with intervention reports mainly concentrate in the firm report category. We performed a test of the difference-in-mean of the intervention frequency for the sample periods 2005-2007 and 2008-2010 and we found that the null of equality in the mean is rejected in all eight countries at all conventional significance levels. The results clearly suggest that the average intervention frequency has intensified post-2008. ${ }^{12}$

- Figure 1 about here -

Figures 1(a) to (h) plot the value of the US dollar against the Asian currencies of all eight countries. The plot is superimposed against the intervention dummy, which indicates purchases $(+1)$ and sales $(-1)$ of the US dollar. The figures show that the central banks of India, Indonesia, Philippines, South Korea, Taiwan, and Thailand intervened constantly to keep their exchange rates from falling against the US dollar from 2007 to 2008 and after 2009. The various countries also responded differently to the rise in the value of the US dollar from 2008 to 2009. Some countries allowed their local currency to appreciate more against the US dollar, while others intervened massively to hold their exchange rate to fluctuate within a

\footnotetext{
12 For brevity, we do not report the difference-in-mean test results but they are available from the authors upon request.
} 
limited range. This is consistent with the notions that some countries monitor the region's exchange rates and attempt to keep the relative value of their currencies in line with the value of selected regional currencies.

It is clear from these figures that most central banks in Asian countries tend to purchase (sell) US dollars when the US dollar depreciates (appreciates), which indicates that these countries are attempting to counter large changes in the value of their domestic currencies in the sample period. Another noteworthy observation is that in several of these Asian countries there are many episodes of intervention occurring on the same day, implying persistence by the authorities in coordinating with market participants to influence the level of the exchange rate.

On May 22, 2013, U.S. Federal Reserve Chairman Ben Bernanke stated in testimony before Congress that that Fed may taper the size of the bond-buying program (or quantitative easing, QE). While Bernanke's surprising pronouncement led to substantial turmoil in the financial markets during the second half of 2013, the Fed did not officially announce its first reduction in QE until December 18, 2013. The reason for this move was that the economy had become strong enough for the Fed to feel confident in reducing the level of stimulus. We note that the number of firm reports increased for all countries except Singapore in the period from May 22 to November 30, 2013 compared to the period prior to the tapering announcement, holding the duration constant. Specifically, the number of intervention after Bernanke's tapering announcement in May 22, 2013 increases with more sales (purchase) of US dollar in India, Indonesia, Malaysia and Thailand (Philippines, South Korea and Taiwan). ${ }^{13}$

\footnotetext{
13 The graphs, which are not reported here for brevity, are plotted for the period 2012/11/21 to 2013/11/29 with the tapering announcement date on 2013/5/22 dividing the sample into equal period. It was found that India and Singapore responded very differently after the tapering announcement; Singapore intervened prior to tapering announcement but did not respond post-announcement, while 


\section{Methodology and Empirical Results}

\subsection{Methodology}

\subsubsection{Defining intervention success}

Following Humpage (1999), we specify three success criteria, which include a broad criterion and two component criteria. We treat each criterion as an official prediction of exchange rate movements and test whether intervention has forecast value using a nonparametric test proposed by Merton (1981) and Henriksson and Merton (1981).

Criterion 1 in the following equation represents the broad measure of success:

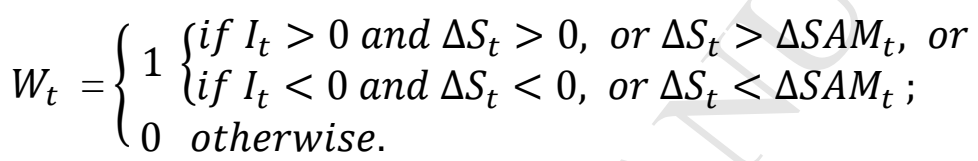

$w_{t}$ equals one which implies success if intervention purchases (sales) of US dollars are associated either with dollar appreciations (depreciations) at time $t$, or with smaller dollar depreciations (appreciations) when comparing $\Delta S_{t}$ with $\Delta S A M_{t} . I_{t}$ designates official intervention at time $t$ with positive (negative) values being purchases (sales) of US dollar intervention; $\Delta S_{t}=S P M_{t}-S A M_{t}$, where $S A M$ and $S P M$ are, respectively, morning and afternoon exchange rates expressed as foreign currency units per dollar, and $\Delta S A M_{t}=S A M_{t}-S A M_{t-1}$. The morning-to-closing analysis is used to capture short-lived market response to intervention.

To examine the nature of the response, we break the general success criterion (Equation (1)) into its two component parts. The first component of the general criterion (criterion 2) counts a success if $w 1_{t}$ equals one, i.e. intervention by Asian countries is successful if a dollar appreciation (depreciation) accompanies an

India did the reverse. Indonesia continued to buy US dollar and the intervention intensified post-announcement. South Korea and Taiwan appeared to intervene intensively around about the same time between August and September of 2013. 
intervention purchase (sale) of US dollars.

$$
w 1_{t}=\left\{\begin{array}{l}
1\left\{\begin{array}{l}
\text { if } I_{t}>0 \text { and } \Delta S_{t}>0, \text { or } \\
\text { if } I_{t}<0 \text { and } \Delta S_{t}<0
\end{array}\right. \\
0 \text { otherwise. }
\end{array}\right.
$$

The second component of the general criterion (criterion 3), which is consistent with "leaning-against-the-wind" strategy, counts a success if $w 2_{t}$ equals one, i.e. an intervention purchase (sale) of US dollars accompanies a smaller dollar depreciation (appreciation).

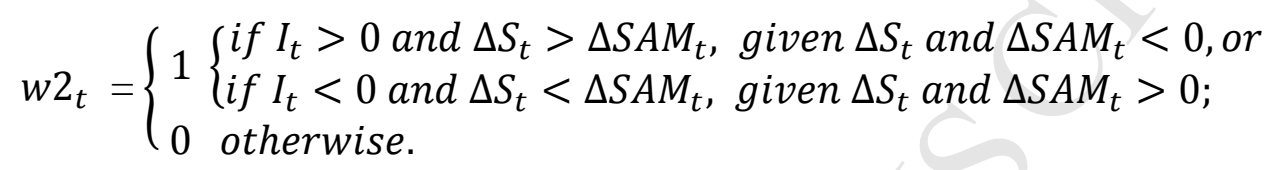

To ensure that our results are not biased by any day-of-the-week effects on exchange rates, we fit at $\operatorname{ARMA}(1,1)$ model with Monday, Tuesday, Wednesday and Thursday dummies on $\Delta S_{t}$. We fail to find any evidence of such effects, which is consistent with the findings of Yamori and Kurihara (2004) who observe that day-of-the-week effects in exchange rates are no longer prevalent in the 1990s.

\subsubsection{Testing the forecast value of intervention}

Merton (1981), Henriksson and Merton (1981) develop a nonparametric test to evaluate investment managers' forecasting skills. Humpage (1999) apply it to central bank intervention by treating each success criterion as an official forecast of near-term dollar movements. Following Humpage (1999), we use this method to assess the forecasting ability of central bank interventions in Asian countries. Evidence of positive forecasting skills would imply that monetary authorities of Asian countries possess superior information.

For example, consider Asian central banks purchase of US dollars and the general success criterion 1 , and define:

$$
p 1=\operatorname{prob}\left[I_{t}<0 \mid \Delta S_{t}<0, \text { or } \Delta S_{t}<\Delta S A M_{t}\right]
$$




$$
\begin{aligned}
& 1-p 1=\operatorname{prob}\left[I_{t} \geq 0 \mid \Delta S_{t}<0, \text { or } \Delta S_{t}<\Delta S A M_{t}\right] \\
& p 2 \quad=\operatorname{prob}\left[I_{t} \geq 0 \mid \Delta S_{t}>0, \text { or } \Delta S_{t}>\Delta S A M_{t}\right] \\
& 1-p 2=\operatorname{prob}\left[I_{t}<0 \mid \Delta S_{t}>0, \text { or } \Delta S_{t}>\Delta S A M_{t}\right]
\end{aligned}
$$

In equation (4), $p 1$ is the probability that intervention sale of US dollar by an Asian central bank on day $t$ conditional on the exchange rate conforming to the success criterion given by equation (1). In equation (6), $p 2$ is the probability that the central bank does not sale dollar on day $t$ conditional on the foreign exchange rate not conforming to the success criterion of equation (1). Equations (5) and (7) are the complementary equations for equations (4) and (6).

The null hypothesis that intervention provides no value is equivalent to $p 1=1$ $p 2$ or $p 1+p 2=1$. Market participants would not revise their prior estimates of the distribution of exchange rate changes as a result of intervention. Intervention has positive (negative) forecast value if $p 1+p 2>1(p 1+p 2<1)$. In the case when $p 1+p 2>1$, market participants can profit from trading in the direction with which Asian central banks intervene in the foreign exchange market. On the other hand, if $p 1+p 2<1$, market participants could profitably bet against Asian central banks.

The number of effective US dollar purchases (sales) by Asian central banks under the null hypothesis has a hypergeometric distribution (Henriksson and Merton, 1981, Humpage, 1999), which is independent of the conditional probability or the underlying distribution of the change in exchange rates. In Table 2, if one minus the cumulative density function (CDF) for the hypergeometric distribution is less than 0.01 , we reject the null in favor of a positive forecast value. If $1-\mathrm{CDF}$ is greater than 0.99 , we reject the null in favor of a negative forecast value.

\subsubsection{Determining the odds of successful intervention}


Using the logistic density function, we estimate the conditional probabilities of successful interventions by Asian central banks. The following logit function measures the odds of success as

$$
\widehat{L}_{i}=\ln \left(\frac{\hat{P}_{i}}{1-\hat{P}_{i}}\right)=X_{i} \hat{b}+u_{i}
$$

, where $\widehat{P}_{i}$ is the probability of a successful intervention, which is estimated by the relative frequency of successes in $n$ trials. $X_{i}$ is a $(1 \times K)$ vector of explanatory variables, which may affect the probability of successful intervention by Asian central banks. $\hat{b}$ is a $(K \times 1)$ vector of estimated parameters.

The first explanatory variable used in this paper is the aggregate number of news on day $t$ (NEWS). Ideally one would measure the success of intervention using the intervention amount, which accords with the portfolio-adjustment theory of exchange rate determination (Humpage, 1999). Due to the lack of intervention amounts data for Asian countries, we construct a proxy for intervention amounts using the number of aggregate intervention news on a specific day. However, given intervention news reports, NEWS, and exchange rate movements are endogenous, the estimated coefficients would be biased. We show in section 4.1.4 how the problem of endogeneity can be circumvented by using Heckman's (1979) two-step procedure.

The second explanatory variable is the number of different sample countries intervening on the same day (COUN). Past studies have shown that coordinated interventions have a bigger impact on exchange rates than do unilateral interventions (Dominguez and Frankel, 1990, 1993). Humpage (1999) finds that coordinated interventions with Germany and Japan increase the odds of successful intervention against the USD. In our sample, the highest number of coordinated interventions is in South Korea (96 days), and the lowest is in Singapore (11 days). 
The third explanatory variable we used is a dummy variable that equals one when intervention day $t$ is the first intervention day in the past five business days (FIRS). This is in accordance with Humpage's (1999) observation that intervention tends to take place over a number of consecutive days, followed by a number of days of inaction. More often than not, the first intervention of a chain of interventions has a more dominant effect on exchange rates than subsequent ones, implying that the first intervention signals more information to the market than latter interventions.

In addition, we include a fourth variable explanatory variable, SUPP, which is a dummy variable that equals one when official statements supporting interventions appeared on day $t$. We argue that such statements are likely to carry weight in influencing market expectations and will, therefore, increase the likelihood of intervention success.

Finally, the last explanatory variable is a dummy variable equals one when official intervention reports are neutral (NEUT). This variable is used to test whether neutral reports provide any information regarding the odds of intervention success. Because some countries may not have enough official statements about supporting interventions or neutral news reports to warrant the estimation coefficients, these variables are not included when estimating the logit regressions.

To account for the impact of coincidental reports of other events on the chances for intervention success, we include dummy variables for the announcements of changes of repurchase rate (RR), interest rate (IR), interbank overnight rate (IOR), gross domestic product (GDP), consumer price index (CPI), balance of trade (BOT), and current account balance $(\mathrm{CAB})$ of each country in our sample. Only results for reported macroeconomic announcements are presented for brevity and results with all variables are available upon request. 


\subsubsection{Intervention reaction function}

Because intervention and exchange rate movements are endogenous estimated coefficients for the variables in equation (8) could be biased. To circumvent the problem of endogeneity, we estimate an intervention reaction function. The logit model in (8) includes the absolute value of the reaction function's predicted interventions that correspond to observed interventions. Intervention reaction functions typically include an exchange rate target, and a measure of volatility, which reflects market disorder (Edison, 1993). We follow this pattern in modeling the decision to intervene, but include a separate equation for the intensity of intervention proxied by the numbers of intervention news reports.

Because Asian central banks may intervene out of concern for both the level and the volatility of their exchange rates, we estimate the intervention reaction function using both ten-day moving average (MOVAG) and a ten-day rolling standard deviation (SIG) of each country. ${ }^{14}$ It was indicated in the literature review that shorter-term exchange rate fluctuations could be used as an early warning indicator to help signal circumstances where there might be misalignment or destabilising market activities. Equation (9) describes the intervention reaction functions for Asian central banks:

$$
Z_{t}^{*}=\mathrm{V}_{\mathrm{t}} \mathrm{a}+u_{t}
$$

where $V_{t} a=\hat{a}_{0}+M_{0 V A G} \times \hat{a}_{1}+\operatorname{SIG}_{t} \times \hat{a}_{2}$.

To construct a reaction function with unbiased parameter estimates, we estimate

\footnotetext{
14 The use of 10-day moving average is consistent with that of Humpage (1990). While the co-ordination channel views intervention as motivated by exchange rate misalignment from its long-run value, the intervention practices of many Asian countries in the period after the global financial crisis are associated with short-term exchange rate movements and excess volatility. For robustness check, we performed the regression using a 30-day moving average. The results remain qualitatively unchanged.
} 
a probit model for the decision to intervene and calculate the inverse Mills ratio. We then estimate a separate equation for the number of intervention reports, using the inverse Mills ratio to control for sample selection bias (Heckman, 1979).

$y_{t}$ is the number of intervention reports in Asian countries. We estimate the number of news report in equation (10):

$$
y_{t}=W_{t} g+\varepsilon_{\mathrm{t}}
$$

where $W_{t} g=\hat{g}_{0}+\Delta S A M_{t} \times \hat{g}_{1}$. Here, $y_{t}$ is observable only when $Z_{t}^{*}>0$. Assuming both $\mu_{t}$ and $\varepsilon_{t}$ follow a bivariate normal distribution with mean zero and variances gives by $\sigma_{\mu}^{2}$ and $\sigma_{\varepsilon}^{2}$, and their correlation, $\rho$, we can obtain the conditional expectation of $y_{t}$ as

$$
\begin{aligned}
\mathrm{E}\left(y_{t} \mid y_{t} \text { is observed }\right) & =\mathrm{E}\left(y_{t} \mid Z_{t}^{*}>0\right) \\
& =W_{t} g+\mathrm{E}\left(\varepsilon_{t} \mid y_{t}>-V_{t} \mathrm{a}\right) \\
& =W_{t} g+\rho \sigma_{\varepsilon} \sigma_{\mu}\left[\phi\left(V_{t} \mathrm{a}\right) / \Phi\left(V_{t} \mathrm{a}\right)\right]
\end{aligned}
$$

where $\phi\left(V_{t} \mathrm{a}\right)$ is the normal density function, and $\Phi\left(V_{t} \mathrm{a}\right)$ is the cumulative normal density function. The term in the square bracket on the right-hand side of the final expression in equation (11) is the Mills ratio, which corrects for sample selection bias.

\subsection{Empirical Results}

\subsubsection{Did Asian central banks successfully intervene in the foreign exchange} market?

Table 2 presents the results of successful intervention and its predicted value for the firm intervention news category. The results show that most Asian central banks with the exception of India have adopted a leaning-against-the-wind strategy 
and intervened more often by purchasing US dollars to halt the rise of their own currencies when the US dollar depreciated.

The effectiveness of central bank intervention varies among Asian countries in Panels A to $\mathrm{H}$ of Table 2. By definition, $p 1$ is the probability that a central bank in an Asian country sell US dollar on day t conditional on the exchange rate conforming to the success criteria. We find that the number is small compared to $p 2$, which is the probability that the central bank does not sell US dollar on day t conditional on the foreign exchange rate not conforming to the success criteria. Even when interventions were completely ineffective and randomly undertaken, the martingale nature of exchange rate changes would insure that it often appeared successful. The "virtual successes", which counts the number of times the exchange rate mimicked a success criterion without central bank intervention, indicates that exchange rates conformed to the general success criterion on sixty percent of the sample days. For six of the sixteen general success categories in Table 2, the frequency of actual successes exceeds that of virtual successes.

Using the broad success criterion 1 , we can reject the null hypothesis at the $95 \%$ confidence level in favor of a positive forecast value $(p 1+p 2>1)$ for the purchases and sales of US dollar intervention in Malaysia, Singapore and Thailand. This suggests that interventions have positive values as recent exchange rate changes will reverse after interventions by these three countries. The economic significance of this result is that central banks in these countries possess superior information which intervention conveys to foreign exchange market. In terms of criterion 2, we show that the null hypothesis can be rejected at the $95 \%$ confidence level in favor of a positive forecast value for purchases of US dollar intervention in all eight Asian counties, and for sales of US dollar intervention in Indonesia, 
Philippines, and Taiwan. This overwhelming result is indicative that market participants can profit from trading in the direction with which Asian central banks intervene in the foreign exchange market.

Results based on criterion 3 indicate that interventions are more effective in reducing local currency changes against the US dollar. We can reject the null hypothesis at the $95 \%$ confidence level in favor of a negative forecast value $(p 1+p 2<$ 1) in seven of the eight countries for purchases of US dollar intervention and all the eight countries for sales of US dollar intervention. These results imply that purchases (sales) of US dollar intervention lead to a smaller local currency appreciation (depreciation) against the US dollar, which is consistent with the notion that Asian countries have adopted a leaning-against-the-wind intervention policy. The negative values indicate that recent exchange rates changes will moderate, but will not reverse.

\section{- Table 2 about here -}

For criterion 3, the percentage of actual successes always exceeds the virtual success. This suggests that, for the most part, the frequency of success under criterion 3 is greater than that of a random event. We can reject the null hypothesis of no forecast value for purchases and sales of US dollars intervention by Asian central banks with a high level of confidence under criterion 3. Together, the evidence suggests that firm intervention reports have substantive predictive power on the near-term exchange rate movements, and that market participants can benefit from the information conveyed to market through central bank intervention. Results in this section are based on firm intervention reports. ${ }^{15}$ The next two sections of the

\footnotetext{
15 Between 2009 and 2013, South Korea, Thailand and Indonesia, amongst other countries introduced controls to discourage inflows of hot money that they feared would drive their currencies to uncompetitive levels. The type of capital controls are "soft" controls which involve market based taxes on certain types of flows, changes to withholding taxes and differential reserves, and liquidity requirements for foreign funds. To measure the extent of capital control, we use the "ka" index
} 
paper demonstrate that various aspects of how Asian central bank undertake their interventions and factors which can increase the probability of their successes.

\subsubsection{What factors drive central bankers to intervene?}

Table 3 presents the estimates of the reaction functions for our sample countries. It can be seen from the negative and statistically significant coefficient of MOVAG that central banks in six of the eight countries with the exception of Indonesia and Taiwan that they tend to intervene in the markets when their own currencies appreciate against the US dollar. In addition, exchange rates in six of the eight countries with exception of Thailand and Malaysia are more volatile as shown in the ten-day rolling standard deviation, which also increases the probability of interventions. This result is consistent with the view put forward by BIS (2013) about the intervention experience of many of the Asian central bankers who intervene to calm disorderly market during period of high capital inflows. It is interesting to note that only the coefficient of $\Delta \mathrm{SAM}_{\mathrm{t}}$ for Singapore and Taiwan is statistically significant at the conventional significance level, which suggests that there are more intervention reports for these countries when their currencies have higher exchange rate changes $\left(\Delta \mathrm{SAM}_{\mathrm{t}}\right){ }^{16}$

- Table 3 about here -

developed by Fernandez et al. (2015). The index has a range of 0 to 1 with 1 denoting high capital control and 0 denoting no capital control. To conserve space, we do not report the index of the 8 countries over time. We found that Singapore and South Korea exhibit the lowest ka index. Based on the index average, we classified the countries into two groups; an average above (below) 0.5 is high (low) capital control countries. The high capital control countries are India, Indonesia, Malaysia, Philippines, and Thailand, while the low capital control countries are South Korea and Singapore. The empirical analysis on the success of intervention is performed on these two groups of countries excluding Taiwan as there is no ka index for Taiwan. We found that intervention based on the general criterion is effective for sales of US dollar in countries with high capital control. However, for criteria 2 and 3, purchases of US dollar are found to be effective in moderating the change in exchange rate movements for both high and low capital control countries. These results are available from the authors upon request.

${ }^{16}$ We perform the analysis using a 30-day moving average and the results remain qualitatively unchanged. To conserve space, the results are not reported by they are available from the authors upon request. 


\subsubsection{What determine the odds of successful intervention?}

Having estimated the intervention reaction function, we obtain NEWSHAT to proxy for the number of intervention reports, which adjusts for sample selection bias. Table 4 presents the odds of successful interventions, according to the broad criterion 1. It can be seen that the odds of successful interventions according to this criterion increase significantly with the number of firm intervention reports in all six countries except Thailand. However, the coefficient estimates of NEWSHAT for Indonesia, Philippines and South Korea are virtually zero to make any economic significance. Based on the estimated coefficient, the increase in the odds of successful intervention from having no firm intervention report to having one firm intervention report is about $50 \%$ for India, Malaysia, Singapore, and Taiwan, all things remaining unchanged. In other words, the probability of a successful intervention for India, Malaysia, Singapore, and Taiwan is virtually close to 1 when there is a firm intervention report. The probability of having no firm intervention report is 0.5 , ceteris paribus. Consequently, having a firm intervention report significantly improves the likelihood of intervention success in India, Malaysia, Singapore and Taiwan.

The odds of successful interventions increase significantly with the number of coordinated interventions (i.e. COUN) and with the first intervention day in the past five business days (i.e. FIRS) for all the countries. When no country is jointly intervening on the same day, the probability of successful intervention is 0.5 . When another country jointly intervenes on the same day, the probability of successful intervention goes up by $32 \%$ for South Korea (the highest increase in the odds) and $23 \%$ for Taiwan and Indonesia (the lowest increase in the odds). When two countries jointly intervene on the same day, the increase in probability from that of having just 
one country jointly intervene is about $28 \%$ for all countries. In other words, on average, when there is a joint intervention between two countries, the odds of successful intervention are about $78 \%$. This increment in the odds of successful intervention is economically significant. This result is consistent with Humpage (1999) who finds that coordinated intervention has a propensity to increase the odds of successful intervention.

The dummy for the first intervention day in the past five business days displays significant explanatory power and has a dominant influence on the probability of successful intervention. On average, the probability increases by as much as about $48 \%$ in all countries. This is economically significant as the odds of successful first day intervention in the past five business days are about $98 \%$. This result suggests that most of the information, which is critical for shaping market perception about exchange rates in Asian countries is prevalent in the first of five business days of interventions. Our result contrasts that of Humpage (1999) who does not find that first day intervention exerts a significant influence on increasing the odds of successful intervention.

When an official statement supporting interventions (neutral reports) has appeared in Reuters' news reports, six (five) of the eight countries show statistically significant results. Although the results suggest that both types of news increase the odds of successful intervention, the increase in the odds of success is higher for a supporting intervention statement than for a neutral statement. The presence of an official supporting statement increases the odds of successful intervention by $42 \%$ on average. This is economically significant and it is effective in increasing the odds of successful intervention as official supporting statement is less likely to be subjected to misinterpretation by market participants. 
- $\quad$ Table 4 about here -

Table 5 provides the results for the joint significance of the explanatory variables. The results are presented according to a number of benchmark covariates. Taking the case of India as an example, the first benchmark covariate is NEWSHAT, as this variable is not only statistically significant, but it also has the highest magnitude for its coefficient than the other variables in Table 4. In each benchmark regression, additional variables are added one at a time to the benchmark covariate(s) and model adequacy is evaluated using the likelihood ratio test. LR test 1 reports the test statistic for the null that the coefficients of the covariates other than the intercept are all equal to zero. LR test 2 reports the test statistic for the null that coefficients of the additional covariates other than the benchmark covariates are equal to zero. The purpose of LR test 2 is to determine the joint significance of the additional variables other than the benchmark covariate(s). For this reason, LR test 2 provides the basis of the subsequent benchmark covariates.

Following on from the example of India, the second set of benchmark covariates is determined by the results of the first set of benchmark regressions with NEWSHAT as the sole benchmark covariate. Here, COUN displays the highest likelihood ratio test value from LR test2 (i.e. 90.27) in Table 5 compared to the other variables, and hence the second benchmark covariates are NEWSHAT and FIRS. The third benchmark covariates are determined using the LR test 2 results of the second set of benchmark regressions. COUN clearly has the highest test statistic value (of 60.97) for LR test2, and NEWSHAT, FIRS and COUN form the third set of benchmark covariates. Following this process of inference, the last benchmark covariates for India are NEWSHAT, FIRS and SUPP. We apply the same process of inference to set up the benchmark covariates to the other countries in our sample. 
Referring to the benchmark covariates (2) to (4) for India, whenever the variable NEUT is added to the regressors, the test statistic of LR test2 fails to become statistically significant at the $5 \%$ level, implying that neutral reports of intervention by Reuters do not have any explanatory power on the odds ratio. It can be seen based on the different permutation and combination of covariates across all eight countries, three covariates, namely NEWSHAT, FIRS and COUN are key to improving the odds of successful intervention in all eight countries. In sum, the success of intervention relies heavily on the presence of a firm report, a coordinated intervention and the first day of five days of interventions.

- $\quad$ Table 5 about here -

A natural question that arises is whether the results are robust to different categories of intervention news reports. That is, do other news categories (suspected, supports and neutral) have different effects than firm intervention reports? To address this issue, we use firm and suspected news reports and repeat the analysis for the forecast value of intervention. To conserve space, we do not report the empirical results, but we find that the results are qualitatively unchanged based on these intervention reports. These results are available from the authors upon request.

\section{Conclusion}

Given the volatile capital flows experienced by Asian economies in the years following the global financial crisis, foreign exchange market developments and the corresponding interventions by Asian central banks have quickly become pertinent issues. The strong capital flows into Asian economies which have impacted domestic exchange rates has raised macroeconomic and financial stability concerns, as well as the question about what central banks in Asian economies can do about it. Many of the Asian regional central banks intervened in foreign exchange markets, in part to 
rebuild foreign reserves stocks following the Asian financial crisis in which many of their reserves have been depleted while defending their currencies. This paper therefore seeks to address the impact of interventions by Asian central banks on their exchange rates during the period of reserves accumulation and the global financial crisis.

Using an approach that relies on the use of Reuters' news reports as a conservative proxy for Asian central bank interventions, we demonstrate the near-term relationship between Asian central bank intervention and their exchange rates. The results show that leaning-against-the-wind intervention strategies are effective in all eight Asian countries during January 2005 to November 2013. This implies that interventions by Asian central banks provide a value only as a forecast that recent dollar movements would dampen. In particular, for purchases of US dollar intervention, we find that central banks in these countries possess superior information which intervention conveys to foreign exchange market. An important implication of this result is that market participants may be able to utilize this information to make profit from trading in the direction with which Asian central banks intervene in the foreign exchange market. In addition, we find that coordinated interventions significantly improve the odds of effective intervention. The first day of a string of interventions is also associated with higher odds of effective interventions. We also find, by and large, that central banks intervene to smooth the near-term trend of exchange rates and to calm its volatility, thus supporting the view that central banks intervene to calm disorderly market during the credit crisis period.

We have shown that interventions by Asian central banks in the near-term appear successful in altering or moderating exchange rate movements. In the absence of such interventions, we could have observed a more rapid appreciation of 
Asian currencies against the USD during the period of quantitative easing, which could have potentially hurt their export sectors. Moreover, we have identified that in dealing with capital flows' volatility, a collective plan is the key to increasing the likelihood of success. In contrast to the usual standalone actions based on each country's individual needs, we find that unilateral actions may not be sufficient to achieve the desired outcome of influencing the level and direction of exchange rate movements. Given that the first day of a string of days of interventions has a significant impact on influencing market expectations about the exchange rate level and increases the odds of successful intervention, it may be in the interest of central banks to intervene with greater intensity (in terms of intervention volume) on that first day.

Although foreign exchange intervention by central banks may impede the direction and levels of exchange rate movements during the crisis period, it provides only a short-term solution to the problem of volatile capital flows (Humpage, 2013). Recent policy initiatives emphasize the role of macroprudential policy which is designed to address systemic risk. Such risks can emanate from significant macroeconomic shocks like volatile capital flows, which can cause distress in the financial system, cause unwinding of imbalances in the financial system generated by excessive leverage, and contagion risk arising from increasing interconnectedness and herd behaviour. Macroprudential policy takes into consideration the system wide economy, employs early identification of risks and its sources as a first step in the policy-setting process, and adopts the use of various policy instruments that complement monetary policy, which counter the financial cycle. Exchange rate intervention is regarded as an integral part of this macroprudential policy mix. 


\section{References}

Aizenman, J., \& Marion, N. (2003). The High Demand for International Reserves in the Far East: What's Going on?, Journal of Japanese and International Economics, 17, $370-400$.

Baillie, R. (2000). Intervention from an Information Perspective. Journal of International Financial Markets, Institutions and Money, 10, 407-421.

Bank for International Settlements (2005). Foreign exchange market intervention in emerging markets: motives, techniques and implications. BIS Papers No. 24.

Bank for International Settlements (2013). Market volatility and foreign exchange intervention in EMEs: what has changed? BIS Papers No. 73.

Bernanke, B. S. (2010). Rebalancing the Global Recovery. Sixth European Central Bank Central Banking Conference Frankfurt, Germany.

Bird, G., \& Rajan, R. S. (2003). Adequacy of Reserves in the Aftermath of Crises. The World Economy, 26, 873-891.

Bordo, M. D., Humpage O. F., \& Schwartz A. J. (2012). Epilogue: Foreign Exchange Market Operations in the Twenty-First Century. Working paper, Federal Reserve Bank of Cleveland.

Bordo, M. D., Humpage O. F., \& Schwarz A. J. (2012). The Federal Reserve as an Informed Foreign Exchange Trader: 1973-1995. International Journal and Central Banking, 8, 1-29.

Burkhard, L., \& Fischer, A.M. (2009). Communicating policy options at the zero bound. Journal of International Money and Finance, 28, 742-754.

Casas, C., Diez, F.J., Gopinath, G., \& Gourinchas, P. (2016). Dominant Currency Paradigm. Working Paper, Berkeley University.

Chaboud, A. P., \& Humpage, O. F. (2005). An Assessment of the Impact of Japanese Foreign-Exchange Intervention: 1991-2004. Board of Governors of the Federal Reserve System, International Finance discussion papers.

Chang, Y., \& Taylor, S. J. (1998). Intraday Effects of Foreign Exchange Intervention by the Bank of Japan. Journal of International Money and Finance, 17, 191-210.

Chen, S. S. (2011). Currency Manipulation Policy in Emerging Foreign Exchange 
Markets. Working paper, National Taiwan University.

Choi, E.K. \& Jin, H. (2014). Currency intervention and consumer welfare in an open economy, International Review of Economics and Finance, 29, 47-56.

Cook, D., \& Yetman, J. (2012). Expanding Central Bank Balance Sheets in Emerging Asia: A Compendium of Risks and Some Evidence. Bank of International Settlements Working Papers No. 66.

Disyatat, P., \& Galati, G. (2007). The Effectiveness of Foreign Exchange Intervention in Emerging Market Countries: Evidence from the Czech koruna. Journal of International Money and Finance, 26, 383-402.

Domaç, I., \& Mendoza, A. (2004). Is There Room for Foreign Exchange Interventions under an Inflation Targeting Framework?, Evidence from Mexico and Turkey. Working paper.

Dominguez, K. M. (1998). Central Bank Intervention and Exchange Rate Volatility. Journal of International Money and Finance, 17, 161-190.

Dominguez, K. M. (2006). When Do Central Bank Interventions Influence Intra-Daily and Longer-Term Exchange Rate Movements?, Journal of International Money and Finance, 25, 1051-1071.

Dominguez, K. M. (2003). The Market Microstructure of Central Bank Intervention. Journal of International Economics, 59, 25-45.

Dominguez, K. M., Fatum, R., \& Vacek P. (2013). Do Sales of Foreign Exchange Reserves Lead to Currency Appreciation?, Journal of Money, Credit and Banking, 45, 867-890.

Dominguez, K. M., \& Frankel, J. A. (1993). Does Foreign Exchange Intervention Matter? The Portfolio Effect. American Economic Review, 83, 1356-1369.

Fatum, R. (2008). Daily Effects of Foreign Exchange Intervention: Evidence from Official Bank of Canada Data. Journal of International Money and Finance, 27, 438-454.

Fatum, R., \& Hutchison, M. M. (1999). Is Intervention a Signal of Future Monetary Policy? Evidence from the Federal Funds Futures Market. Journal of Money, Credit and Banking, 31, 54-69. 
Fatum, R., \& Hutchison, M. M. (2002). ECB Foreign Exchange Intervention and the EURO: Institutional Framework, News, and Intervention. Open Economies Review, 13, 413-425.

Fatum, R., \& Hutchison, M. M. (2003). Is Sterilised Foreign Exchange Intervention Effective after All? An Event Study Approach. The Economic Journal, 113, 390-411.

Fatum, R., \& Hutchison, M. M. (2006). Effectiveness of Official Daily Foreign Exchange Market Intervention Operations in Japan. Journal of International Money and Finance, 25, 199-219.

Fatum, R., \& Hutchison, M. M. (2010). Evaluating Foreign Exchange Market Intervention: Self-Selection, Counterfactuals and Average Treatment Effects. Journal of International Money and Finance, 29, 570-584.

Fernández, A., Klein, M.W., Rebucci, A., Schindler, M., \& Uribe, M. (2015). Capital Control Measures: A New Dataset. IMF Working Paper WP/15/80.

Fischer, A. M. (2006). On the Inadequacy of Newswire Reports for Empirical Research on Foreign Exchange Interventions. Journal of International Money and Finance, 25, 1226-1240.

Fischer, A.M., \& Zurlinden, M. (1999). Exchange rate effects of central bank interventions: An analysis of transaction prices. Economic Journal, 109, 662-676.

Galati, G., \& Melick, W. (2002). Central bank intervention and market expectations. Bank of International Settlement Working Papers, No. 10.

Goodhart, C., \& Hesse, T. (1993). Central bank forex intervention assessed in continuous time. Journal of International Money and Finance, 12, 644-653.

Goral, A., \& Sanchit A. (2010). The Indian Exchange Rate and Central Bank Action: A GARCH Analysis. Working paper.

Guimaraes, R. F., \& Karacadag, C. (2004). The Empirics of Foreign Exchange Intervention in Emerging Market Countries: The Cases of Mexico and Turkey. IMF working paper 04/123.

Hua, M., \& Gau, Y. (2006). Determinants of Periodic Volatility of Intraday Exchange Rates in the Taipei FX Market. Pacific-Basin Finance Journal, 14, 193-208.

Humpage, O. F. (1999). U.S. Intervention: Assessing the Probability of Success. Journal 
of Money, Credit and Banking, 31, 731-747.

Humpage, O. F. (2003). Government Intervention in the Foreign Exchange Market. Federal Reserve Bank of Cleveland working paper.

Humpage, O. F., \& Ragnartz, J. (2005). Swedish Intervention and the Krona Float, 1993-2002. Federal Reserve Bank of Cleveland working paper.

Ito, T. (2005). Interventions and Japanese Economic Recovery. International Economics and Economic Policy, 2, 219-239.

Ito, T., \& Yabu, T. (2007). What Prompts Japan to Intervene in the Forex Market? A New Approach to a Reaction Function. Journal of International Money and Finance, 26, 193-212.

Jin, H., \& Choi, E.K. (2013). Profits and losses from currency intervention, International Review of Economics and Finance, 27, 14-20.

Kaminsky, G. L., \& Lewis, K. K. (1996). Does Foreign Exchange Intervention Signal Future Monetary Policy? Journal of Monetary Economics, 37, 285-312.

Kearns, J., \& Rigobon, R. (2005). Identifying the Efficacy of Central Bank Interventions: Evidence from Australia and Japan. Journal of International Economics, 66, 31-48.

Leahy, M. (1995). The Profitability of U.S. Intervention in the Foreign Exchange Market. Journal of International Money and Finance, 14, 823-844.

Lewis, K. K. (1995). Are Foreign Exchange Interventions and Monetary Policy Related, and Does It Matter. Journal of Business, 68, 185-214.

Menkhoff, L. (2012). Foreign Exchange Intervention in Emerging Markets: A Survey of Empirical Studies. Working paper.

Merton, R. C. (1981). On Market Timing and Investment Performance. I. An Equilibrium Theory of Value for Market Forecasts. Journal of Business, 54, 363-406.

Neely, C. J. (2011). A Foreign Exchange Intervention in an Era of Restraint. Federal Reserve Bank of St. Louis, Review, 93, 303-324.

Pasquariello, P. (2010). Central bank intervention and the intraday process of price formation in currency markets. Journal of International Money and Finance, 29, 1045-1061. 
Pattanaik, S., \& Sahoo, S. (2003). The Effectiveness of Intervention in India: An Empirical Assessment. Working paper.

Payne, R., \& Vitale, P. (2003). A transaction level study of the effects of exchange rate intervention on exchange rates. Journal of International Economics, 61, 331-352.

Peiers, B. (1997). Informed Traders, Intervention, and Price Leadership: A Deeper View of the Microstructure of the Foreign Exchange Market. Journal of Finance, 52, 1589-1614.

Reitz, S., \& Taylor, M. P. (2008). The Coordination Channel of Foreign Exchange Intervention: A Nonlinear Microstructural Analysis. European Economic Review, 52, $55-76$.

Rincon, H., \& Toro, J. (2011). Are Capital Controls and Central Bank Intervention Effective?, Borradores de ECONOMIA, 625. Banco de la Republica, Colombia.

Sapp, S. G. (2002). Price Leadership in the Spot Foreign Exchange Market. Journal of Financial and Quantitative Analysis, 37, 425-448.

Sarno, L., \& Taylor, M. P. (2001). Official Intervention in the Foreign Exchange Market: Is It Effective and, If So, How Does It Work?, Journal of Economic Literature, 39, 839-868.

Tapia, M., \& Tokman, A. (2004). Effects of Foreign Exchange Intervention under Public Information: The Chilean Case. Economica, 4, 1-42.

Taylor, M. P. (2005). Official Foreign Exchange Intervention as a Coordinating Signal in the Dollar-Yen Market. Pacific Economic Review, 10, 73-82.

Yamori, N., \& Kurihara, Y. (2004). The day-of-the-week effect in foreign exchange Markets: multi-currency evidence. Research in International Business and Finance, $18,51-57$. 


\section{Table 1 Central Bank Intervention News Distribution}

Panel (a) Number of news counts

\begin{tabular}{|c|c|c|c|c|c|c|c|c|c|c|c|c|}
\hline \multirow{3}{*}{ Country } & \multicolumn{3}{|c|}{ Firm } & \multicolumn{3}{|c|}{ Suspected } & \multicolumn{3}{|c|}{ Supported } & \multicolumn{3}{|c|}{ Neutral } \\
\hline & $2005-$ & $2008-$ & Total & $2005-$ & 2008 & Total & $2005-$ & 2008 & Total & $2005-$ & $2008-$ & Total \\
\hline & 2007 & 2013 & & 2007 & 2013 & & 2007 & 2013 & & 2007 & 2013 & \\
\hline India & 48 & 113 & 161 & 66 & 104 & 170 & 4 & 7 & 11 & 1 & 2 & 3 \\
\hline Indonesia & 3 & 253 & 256 & 0 & 32 & 32 & 3 & 40 & 43 & 0 & 15 & 15 \\
\hline Malaysia & 2 & 47 & 49 & 2 & 12 & 14 & 1 & 3 & 4 & 1 & 0 & 1 \\
\hline Philippines & 10 & 139 & 149 & 3 & 39 & 42 & 0 & 13 & 13 & 0 & 10 & 10 \\
\hline Singapore & 1 & 50 & 51 & 4 & 40 & 44 & 1 & 1 & 2 & 0 & 3 & 3 \\
\hline $\begin{array}{l}\text { South } \\
\text { Korea }\end{array}$ & 8 & 271 & 279 & 3 & 108 & 111 & 13 & 75 & 88 & 0 & 20 & 20 \\
\hline Taiwan & 11 & 321 & 332 & 2 & 31 & 33 & 0 & 21 & 21 & 0 & 15 & 15 \\
\hline Thailand & 4 & 161 & 165 & 6 & 35 & 41 & 0 & 42 & 42 & 0 & 14 & 14 \\
\hline
\end{tabular}

Panel (b) Number of days with news reports

\begin{tabular}{lcccc}
\hline Country & Firm & Suspected & Supported & Neutral \\
\hline India & 93 & 102 & 10 & 3 \\
Indonesia & 204 & 25 & 36 & 12 \\
Malaysia & 38 & 12 & 3 & 1 \\
Philippines & 120 & 38 & 12 & 8 \\
Singapore & 43 & 35 & 2 & 3 \\
South Korea & 182 & 93 & 65 & 16 \\
Taiwan & 261 & 24 & 19 & 9 \\
Thailand & 116 & 37 & 34 & 14 \\
\hline
\end{tabular}

Note: A report is classified as a firm report when the news clearly state that the central bank intervened in currency markets. A report is classified as a suspected report when the news cast doubt on official intervention in the foreign exchange market. A report is classified as a supported report when central bank or government officials provide statements that show support for intervention in the currency market (including suggestions that intervention is a possibility). A report is classified as a neutral report when central bank or government officials express a neutral opinion on intervention activities. 


\section{Figure 1 Plots of Asian Currencies viz-a-viz US Dollar and Intervention Dummy}

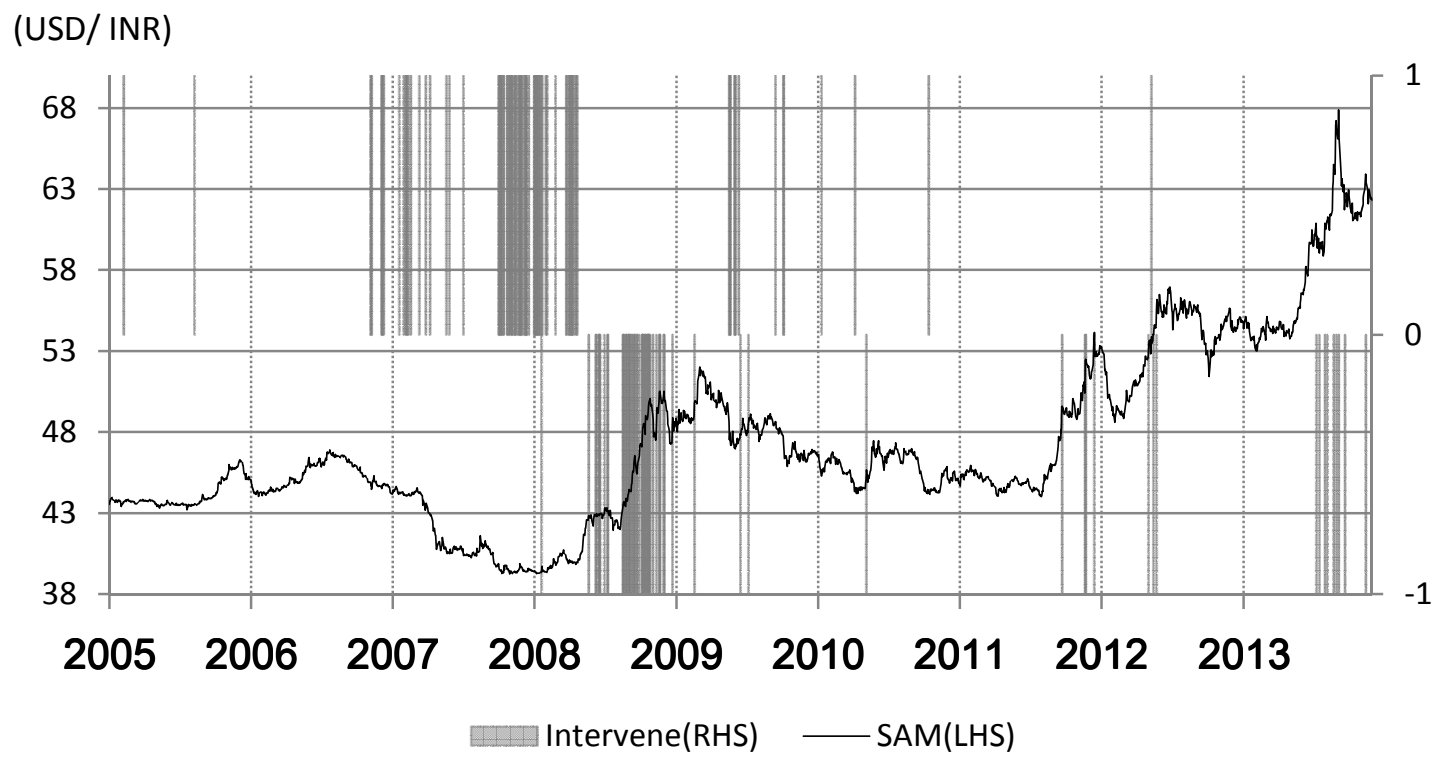

Figure 1(a): India

Intervene is a dummy variable equal to 1 when the central bank of India buys US dollars from the exchange market on certain dates, equal to -1 when the bank sells US dollars, or equal to 0 otherwise. SPM is the daily closing price of USD against the Indian Rupee.

(USD/ IDR)

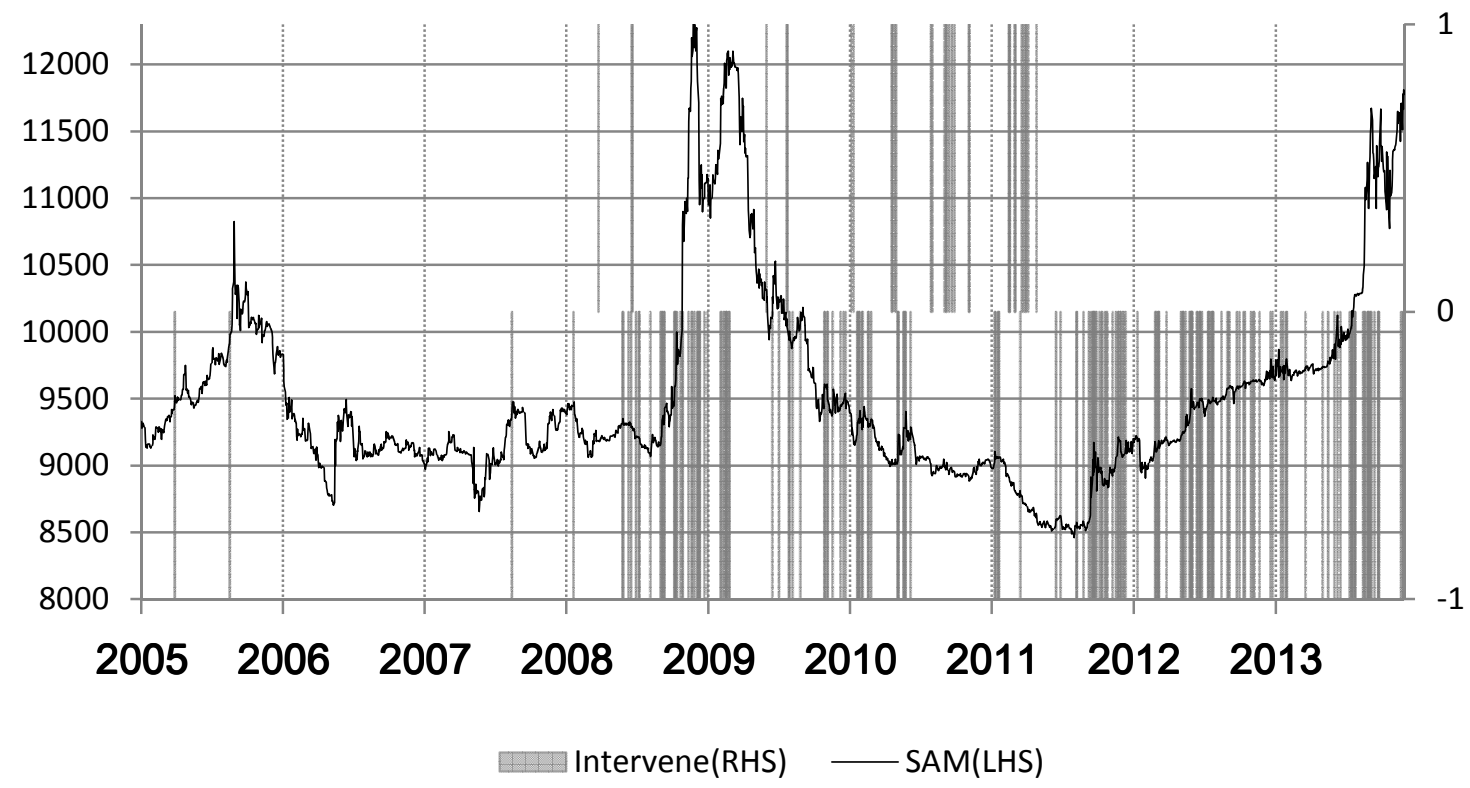

Figure 1(b): Indonesia

Intervene is a dummy variable equal to 1 when the central bank of Indonesia buys US dollars from the exchange market on certain dates, equal to -1 when the bank sells US dollars, or equal to 0 otherwise. SPM is the daily closing price of USD against the Indonesian Rupiah. 
(USD/MYR)

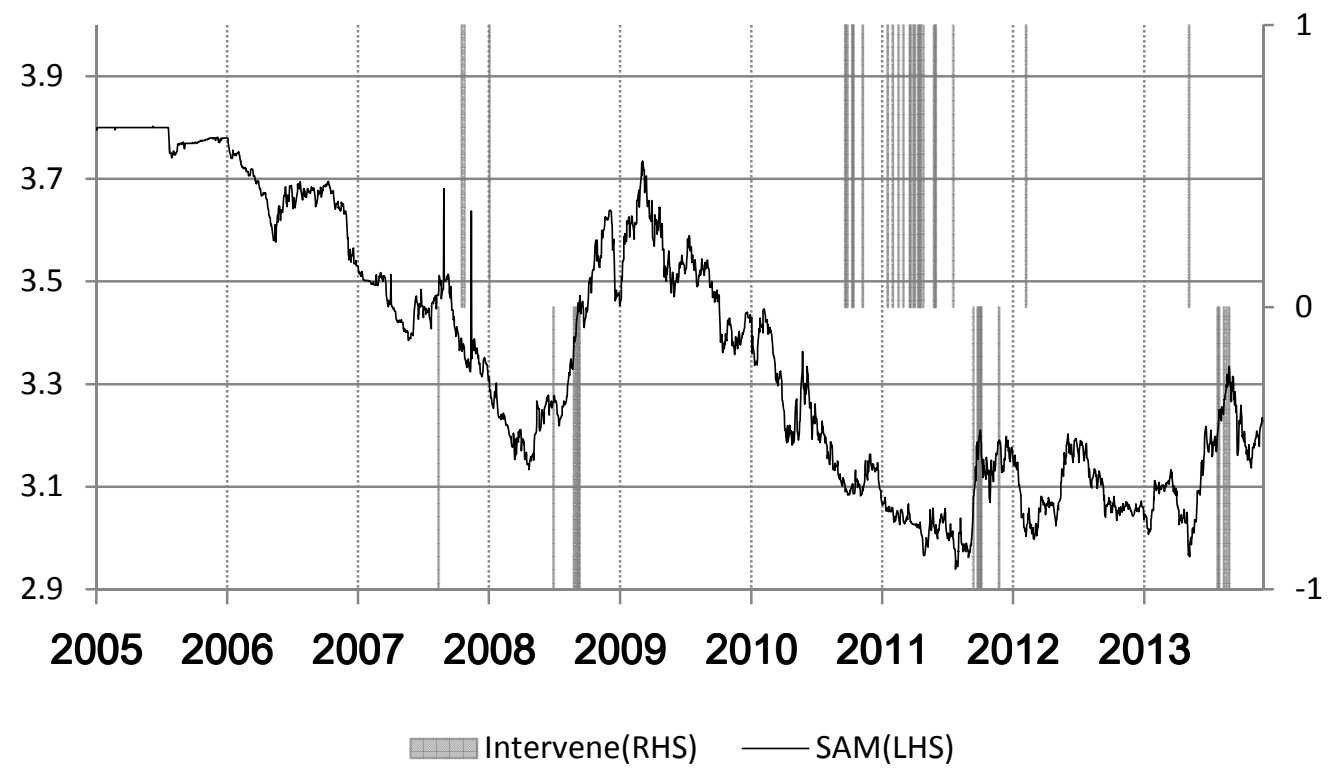

Figure 1(c): Malaysia

Intervene is a dummy variable equal to 1 when the central bank of Malaysia buys US dollars from the exchange market on certain dates, equal to -1 when the bank sells US dollars, or equal to 0 otherwise. SPM is the daily closing price of USD against the Malaysian Ringgit.

(USD/ PHP)

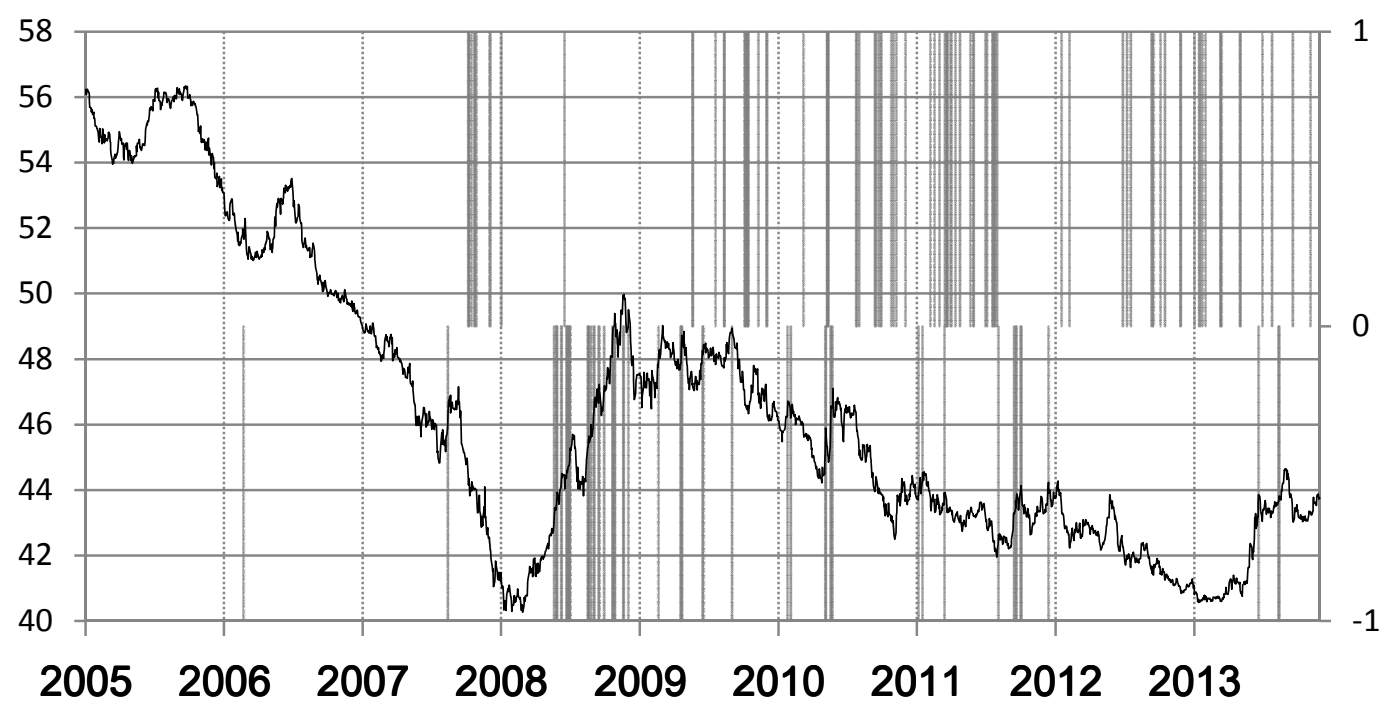

Intervene(RHS) - SPM(LHS)

Figure 1(d): Philippines

Intervene is a dummy variable equal to 1 when the central bank of Philippines buys US dollars from the exchange market on certain dates, equal to -1 when the bank sells US dollars, or equal to 0 otherwise. SPM is the daily closing price of USD against the Philippine Peso. 
(USD/ SGD)

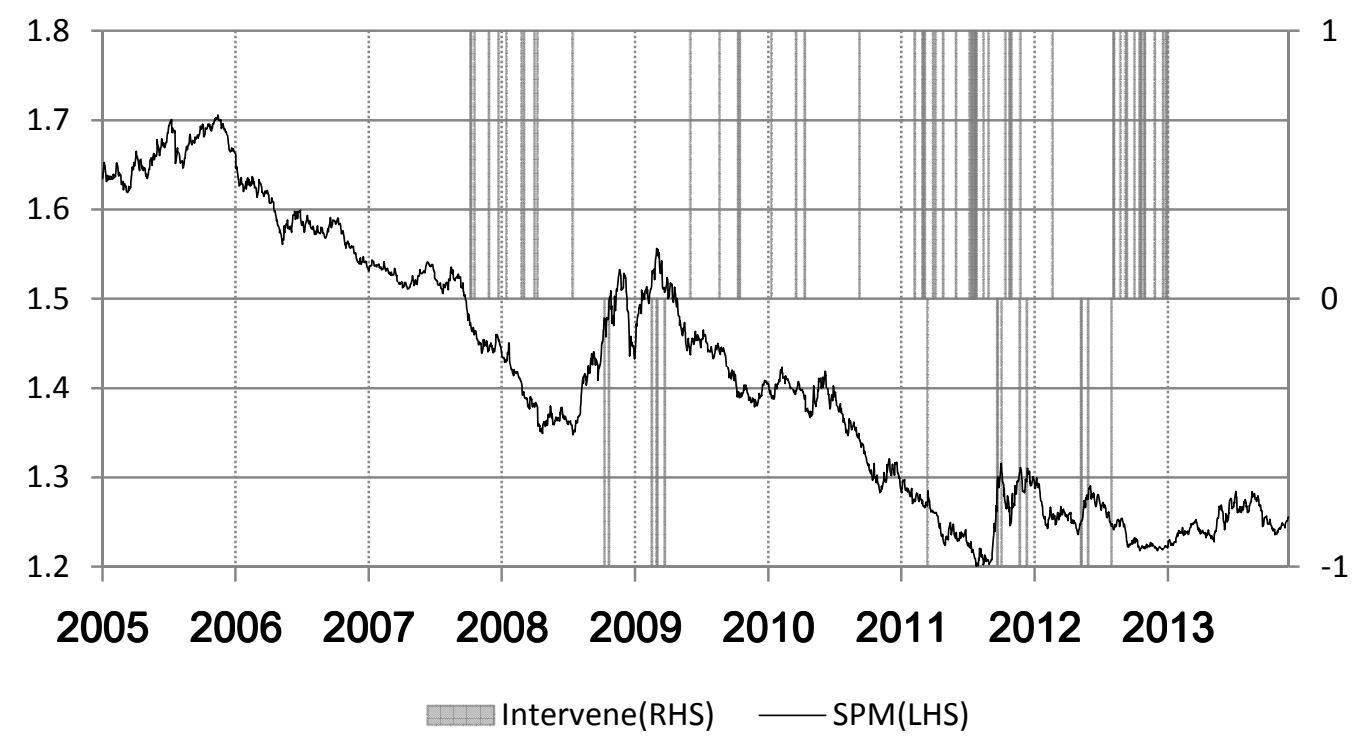

Figure 1(e): Singapore

Intervene is a dummy variable equal to 1 when the central bank of Singapore buys US dollars from the exchange market on certain dates, equal to -1 when the bank sells US dollars, or equal to 0 otherwise. SPM is the daily closing price of USD against Singapore dollars.

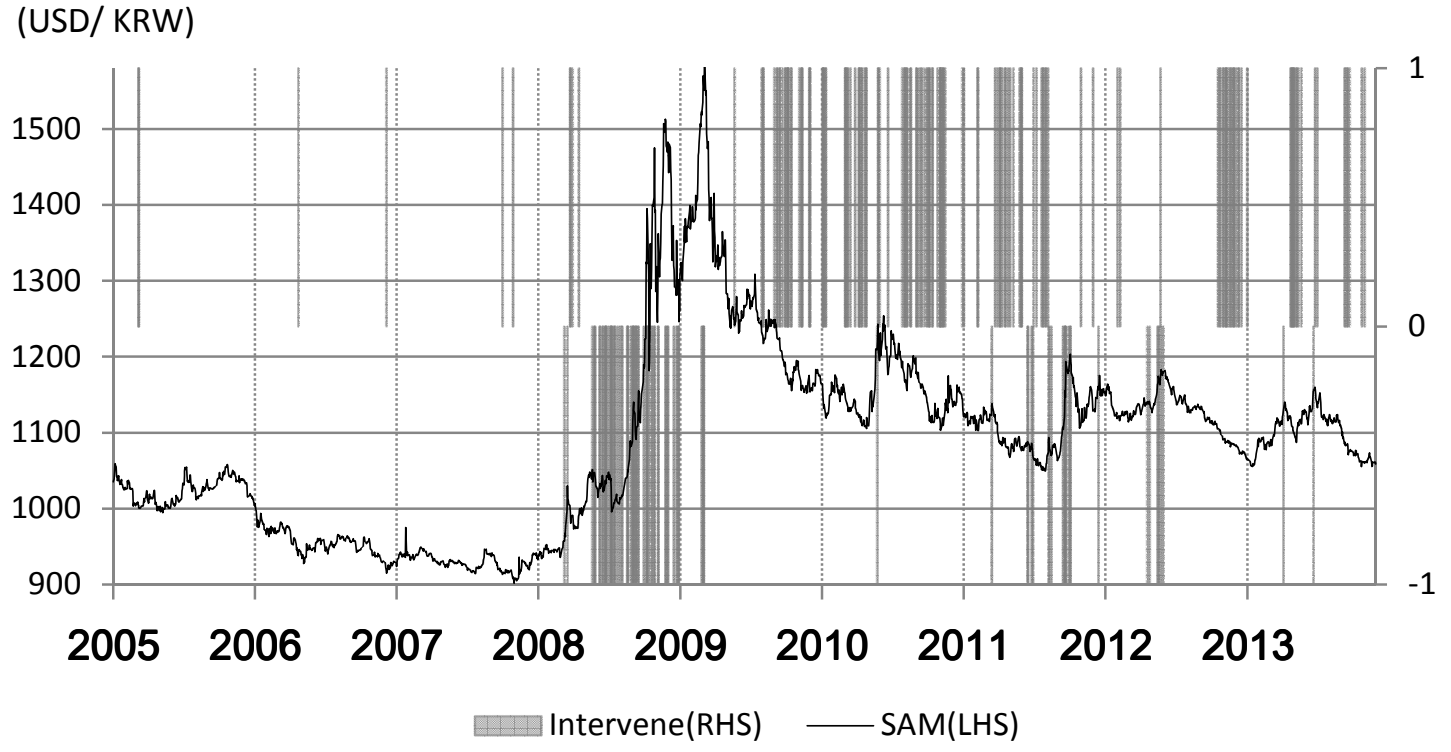

Figure 1(f): South Korea

Intervene is a dummy variable equal to 1 when the central bank of South Korea buys US dollars from the exchange market on certain dates, equal to -1 when the bank sells US dollars, or equal to 0 otherwise. SPM is the daily closing price of USD against the Korean Won. 


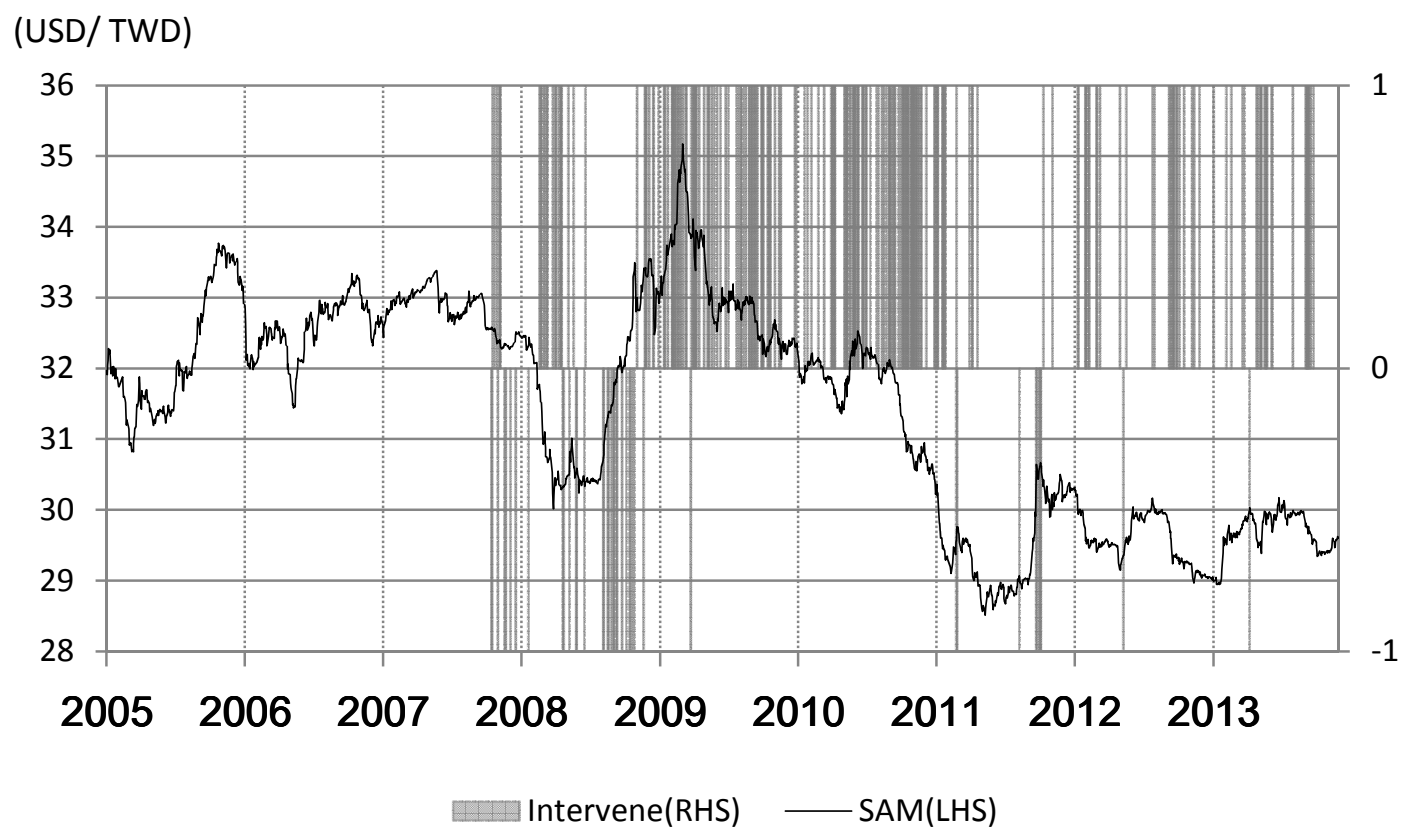

Figure 1(g): Taiwan

Intervene is a dummy variable equal to 1 when the central bank of Taiwan buys US dollars from the exchange market on certain dates, equal to -1 when the bank sells US dollars, or equal to 0 otherwise. SPM is the daily closing price of USD against NTD.

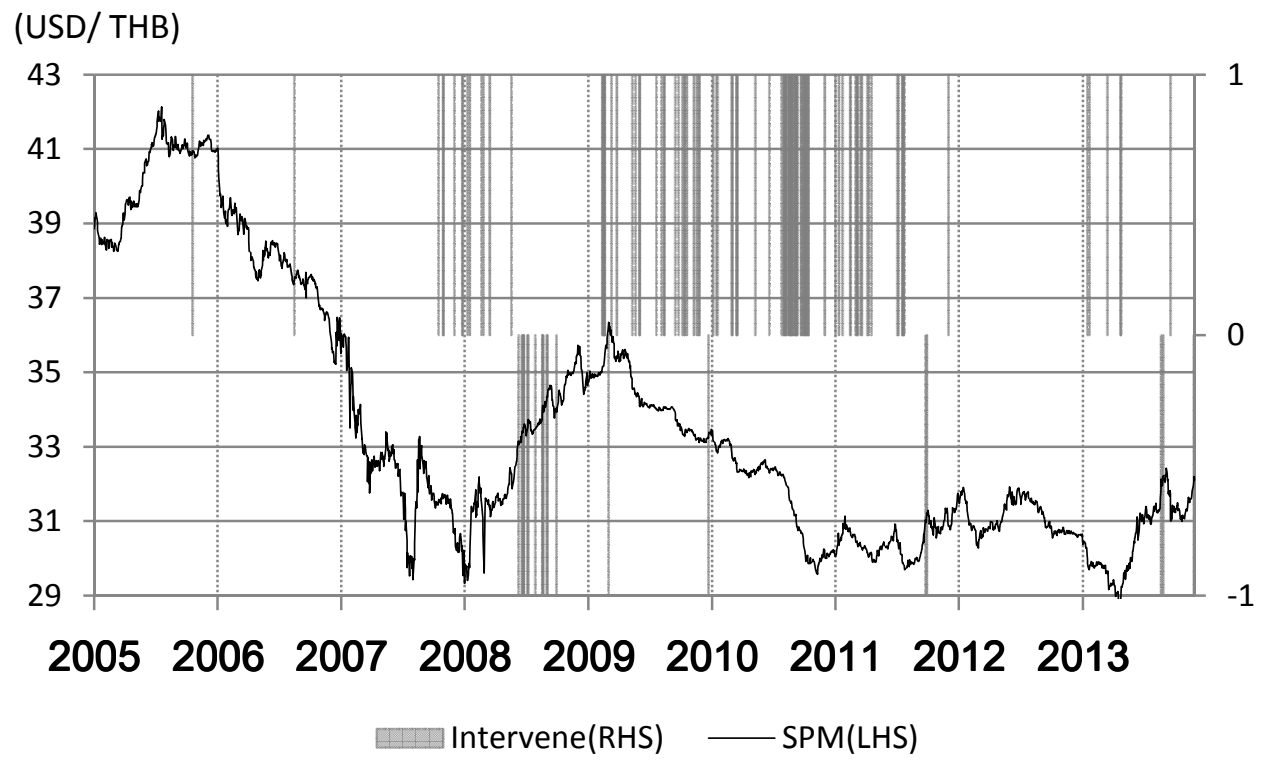

Figure 1(h): Thailand

Intervene is a dummy variable equal to 1 when the central bank of Thailand buys US dollars from the exchange market on certain dates, equal to -1 when the bank sells US dollars, or equal to 0 otherwise. SPM is the daily closing price of USD against the Thai Baht. 
Table 2 Asian Central Bank Intervention and Alternative Success Criteria (Firm News Category)

Figures in columns 2, 3, and 4 are the total number of actual intervention, the number of days of successful exchange rate intervention based on a success criterion, and the percentage of successful intervention, respectively. Figures in columns 5, 6, and 7 are total business days, the number of days of successful exchange rate interventions based on a success criterion, and the percentage of virtual successful intervention, respectively. $p 1$ is the probability that a central bank purchases (or sells) US dollars on day $t$ conditional on the exchange rate conforming to the criterion. $p 2$ is the probability that a central bank does not purchase (or sell) US dollars on day $t$ conditional on the foreign exchange rate not conforming to the criterion. $p 1+p 2$ denotes the prediction value for intervention. The final column is the value of the test statistic given by one minus the cumulative density function (CDF). ***, **, and $*$ denote significance at the $99 \%, 95 \%$ and $90 \%$ confidence levels, respectively.

\begin{tabular}{|c|c|c|c|c|c|c|c|c|c|c|}
\hline & \multicolumn{7}{|c|}{ Panel A: India } & \multicolumn{3}{|c|}{ Y } \\
\hline & \multicolumn{3}{|c|}{ Intervention } & \multicolumn{3}{|c|}{ Virtual } & & \multirow{3}{*}{$\mathrm{p} 2$} & \multirow{3}{*}{$\mathrm{p} 1+\mathrm{p} 2$} & \multirow{3}{*}{$1-\mathrm{CDF}$} \\
\hline & Total & Succ & esses & Total & Succes & sses & $\mathrm{p} 1$ & & & \\
\hline & $\#$ & $\#$ & $\%$ & $\#$ & $\#$ & $\%$ & ( & & & \\
\hline \multicolumn{11}{|l|}{ General } \\
\hline Purchases & 49 & 29 & 59.2 & 2,190 & 1,421 & 64.9 & 0.020 & 0.974 & 0.994 & 0.758 \\
\hline Sales & 44 & 33 & 75.0 & 2,190 & 1,304 & 59.5 & 0.025 & 0.988 & 1.013 & $0.010 * * *$ \\
\hline \multicolumn{11}{|c|}{ Appreciate / Depreciate } \\
\hline Purchases & 49 & 20 & 40.8 & 2,190 & 1,157 & 52.8 & 0.017 & 0.972 & 0.989 & $0.941 *$ \\
\hline Sales & 44 & 17 & 38.6 & 2,190 & 1,010 & 46.1 & 0.017 & 0.977 & 0.994 & 0.803 \\
\hline \multicolumn{11}{|c|}{ Leaning-against-the-wind } \\
\hline Purchases & 49 & & 16.3 & 2,190 & 257 & 11.7 & 0.031 & 0.979 & 1.010 & 0.112 \\
\hline Sales & 44 & 16 & 36.4 & 2,190 & 278 & 12.7 & 0.058 & 0.985 & 1.043 & $0.000 * * *$ \\
\hline \multicolumn{11}{|c|}{ Panel B: Indonesia } \\
\hline & \multicolumn{3}{|c|}{ Intervention } & \multicolumn{3}{|c|}{ Virtual } & & & & \\
\hline & Total & Succ & esses & Total & \multicolumn{2}{|c|}{ Successes } & $\mathrm{p} 1$ & $\mathrm{p} 2$ & $\mathrm{p} 1+\mathrm{p} 2$ & $1-\mathrm{CDF}$ \\
\hline & $\#$ & $\#$ & $\%$ & $\#$ & $\#$ & $\%$ & & & & \\
\hline \multicolumn{11}{|l|}{$\overline{\text { General }}$} \\
\hline Purchases & 25 & 10 & 40.0 & 2,311 & 1,321 & 57.2 & 0.008 & 0.985 & 0.992 & $0.938 *$ \\
\hline Sales & 179 & 117 & 65.4 & 2,311 & 1,440 & 62.3 & 0.081 & 0.929 & 1.010 & 0.169 \\
\hline \multicolumn{11}{|c|}{ Appreciate / Depreciate } \\
\hline Purchases & 25 & 5 & 20.0 & 2,311 & 1,018 & 44.1 & 0.005 & 0.985 & 0.989 & $0.989 * *$ \\
\hline Sales & 179 & 91 & 50.8 & 2,311 & 1,177 & 50.9 & 0.077 & 0.922 & 1.000 & 0.479 \\
\hline \multicolumn{11}{|c|}{ Leaning-against-the-wind } \\
\hline Purchases & 25 & 5 & 20.0 & 2,311 & 253 & 10.9 & 0.020 & 0.990 & 1.010 & $0.048 * *$ \\
\hline Sales & 179 & 23 & 12.8 & 2,311 & 213 & 9.2 & 0.108 & 0.926 & 1.034 & $0.034 * *$ \\
\hline \multicolumn{11}{|c|}{ Panel C: Malaysia } \\
\hline & \multicolumn{3}{|c|}{ Intervention } & \multicolumn{3}{|c|}{ Virtual } & & & & \\
\hline & Total & Succ & esses & Total & Succes & sses & $\mathrm{p} 1$ & p2 & $\mathrm{p} 1+\mathrm{p} 2$ & $1-\mathrm{CDF}$ \\
\hline & $\#$ & $\#$ & $\%$ & $\#$ & $\#$ & $\%$ & & & & \\
\hline
\end{tabular}




$\begin{array}{cllllllllll}\text { Purchases } & 26 & 17 & 65.4 & 2,310 & 1,358 & 58.8 & 0.013 & 0.991 & 1.003 & 0.188 \\ \text { Sales } & 12 & 10 & 83.3 & 2,310 & 1,390 & 60.2 & 0.007 & 0.998 & 1.005 & 0.020 \text { ** }\end{array}$

Appreciate / Depreciate

$\begin{array}{cllllllllll}\text { Purchases } & 26 & 7 & 26.9 & 2,310 & 1,005 & 43.5 & 0.007 & 0.985 & 0.992 & 0.938 * \\ \text { Sales } & 12 & 6 & 50.0 & 2,310 & 1,089 & 47.1 & 0.006 & 0.995 & 1.001 & 0.312\end{array}$

Leaning-against-the-wind

\begin{tabular}{crrrrrrrrrr} 
Purchases & 26 & 10 & 38.5 & 2,310 & 314 & 13.6 & 0.032 & 0.992 & 1.024 & $0.000 * * *$ \\
Sales & 12 & 3 & 25.0 & 2,310 & 268 & 11.6 & 0.011 & 0.996 & 1.007 & $0.041 *$ \\
\hline \hline
\end{tabular}

Panel D: Philippines

\begin{tabular}{|c|c|c|c|c|c|c|c|c|c|c|}
\hline & \multicolumn{3}{|c|}{ Intervention } & \multicolumn{3}{|c|}{ "Virtual } & \multirow{3}{*}{$\mathrm{p} 1$} & \multirow{3}{*}{ p2 } & \multirow{3}{*}{$\mathrm{p} 1+\mathrm{p} 2$} & \multirow{3}{*}{ 1-CDF } \\
\hline & \multirow{2}{*}{$\begin{array}{c}\text { Total } \\
\#\end{array}$} & \multicolumn{2}{|c|}{ Successes } & \multirow{2}{*}{$\begin{array}{c}\text { Total } \\
\#\end{array}$} & \multicolumn{2}{|c|}{ Successes } & & & & \\
\hline & & \# & $\%$ & & \# & $\%$ & & & & \\
\hline \multicolumn{11}{|l|}{$\overline{\text { General }}$} \\
\hline Purchases & 71 & 47 & 66.2 & 2,310 & 1,421 & 61.5 & 0.033 & 0.973 & 1.006 & 0.172 \\
\hline Sales & 49 & 31 & 63.3 & 2,310 & 1,496 & 64.8 & 0.021 & 0.978 & 0.999 & 0.534 \\
\hline \multicolumn{11}{|c|}{ Appreciate / Depreciate } \\
\hline Purchases & 71 & 23 & 32.4 & 2,310 & 1,027 & 44.5 & 0.022 & 0.963 & 0.985 & $0.976 * *$ \\
\hline Sales & 49 & 19 & 38.8 & 2,310 & 1,225 & 53.0 & 0.016 & 0.972 & 0.988 & $0.970 * *$ \\
\hline \multicolumn{11}{|c|}{ Leaning-against-the-wind } \\
\hline Purchases & 71 & 24 & 33.8 & 2,310 & 353 & 15.3 & 0.068 & 0.976 & 1.044 & $0.000 * * *$ \\
\hline Sales & 49 & 11 & 22.4 & 2,310 & 256 & 11.1 & 0.043 & 0.981 & 1.024 & $0.006 * * *$ \\
\hline
\end{tabular}

Panel E: Singapore

\begin{tabular}{|c|c|c|c|c|c|c|c|c|c|}
\hline & \multicolumn{2}{|c|}{ Intervention } & \multicolumn{3}{|c|}{ Virtual } & \multirow{3}{*}{$\mathrm{p} 1$} & \multirow{3}{*}{$\mathrm{p} 2$} & \multirow{3}{*}{$\mathrm{p} 1+\mathrm{p} 2$} & \multirow{3}{*}{$1-\mathrm{CDF}$} \\
\hline & \multirow{2}{*}{$\begin{array}{c}\text { Total } \\
\#\end{array}$} & \multirow{2}{*}{$\begin{array}{c}\text { Successes } \\
\# \quad \% \\
\end{array}$} & \multirow{2}{*}{$\begin{array}{c}\text { Total } \\
\# \\
\end{array}$} & \multicolumn{2}{|c|}{ Successes } & & & & \\
\hline & & & & $\#$ & $\%$ & & & & \\
\hline \multicolumn{10}{|l|}{ General } \\
\hline Purchases & 36 & $25 \quad 69.4$ & 2,308 & 1,464 & 63.4 & 0.017 & 0.987 & 1.004 & 0.177 \\
\hline Sales & 7 & 685.7 & 2,308 & 1,512 & 65.5 & 0.004 & 0.999 & 1.003 & $0.052 *$ \\
\hline \multicolumn{10}{|c|}{ Appreciate / Depreciate } \\
\hline Purchases & 36 & 1027.8 & 2,308 & 1,045 & 45.3 & 0.010 & 0.979 & 0.989 & $0.976 * *$ \\
\hline Sales & 7 & 457.1 & 2,308 & 1,230 & 53.3 & 0.003 & 0.997 & 1.000 & 0.284 \\
\hline \multicolumn{10}{|c|}{ Leaning-against-the-wind } \\
\hline Purchases & 36 & 1541.7 & 2,308 & 396 & 17.2 & 0.038 & 0.989 & 1.027 & $0.000 * * *$ \\
\hline Sales & 7 & 228.6 & 2,308 & 272 & 11.8 & 0.007 & 0.998 & 1.005 & $0.039 * *$ \\
\hline \multicolumn{10}{|c|}{ Panel F: South Korea } \\
\hline & \multicolumn{2}{|c|}{ Intervention } & \multicolumn{3}{|c|}{ Virtual } & & & & \\
\hline & Total & Successes & Total & \multicolumn{2}{|c|}{ Successes } & p1 & $\mathrm{p} 2$ & $\mathrm{p} 1+\mathrm{p} 2$ & $1-\mathrm{CDF}$ \\
\hline & $\#$ & $\%$ & $\#$ & \# & $\%$ & & & & \\
\hline \multicolumn{10}{|l|}{ General } \\
\hline Purchases & 113 & $77 \quad 68.1$ & 2,306 & 1,479 & 64.1 & 0.052 & 0.956 & 1.009 & 0.156 \\
\hline Sales & 69 & $42 \quad 60.9$ & 2,306 & 1,423 & 61.7 & 0.030 & 0.969 & 0.999 & 0.512 \\
\hline \multicolumn{10}{|c|}{ Appreciate / Depreciate } \\
\hline Purchases & 113 & $42 \quad 37.2$ & 2,306 & 1,132 & 49.1 & 0.037 & 0.940 & 0.977 & $0.994 * * *$ \\
\hline & & & 5 & & & & & & \\
\hline
\end{tabular}




\section{ACCEPTED MANUSCRIPT}

Sales

$\begin{array}{llllllll}69 & 34 & 49.3 & 2,306 & 1,153 & 50.0 & 0.029 & 0.970\end{array}$

$0.999 \quad 0.500$

Leaning-against-the-wind

\begin{tabular}{crrrrrrrrrrr} 
Purchases & 113 & 35 & 31.0 & 2,306 & 335 & 14.5 & 0.104 & 0.960 & 1.065 & $0.000 * * *$ \\
Sales & 69 & 8 & 11.6 & 2,306 & 261 & 11.3 & 0.031 & 0.970 & 1.001 & 0.378 \\
\hline \hline
\end{tabular}

\section{Panel G: Taiwan}

\begin{tabular}{|c|c|c|c|c|c|c|c|c|c|c|}
\hline & \multicolumn{3}{|c|}{ Intervention } & \multicolumn{3}{|c|}{ Virtual } & \multirow{3}{*}{$\mathrm{p} 1$} & \multirow{3}{*}{$\mathrm{p} 2$} & \multirow{3}{*}{$\mathrm{p} 1+\mathrm{p} 2$} & \multirow{3}{*}{ 1-CDF } \\
\hline & Total & Succe & esses & Total & Succes & sses & & & & \\
\hline & \# & \# & $\%$ & \# & \# & $\%$ & & & & \\
\hline \multicolumn{11}{|l|}{ General } \\
\hline Purchases & 221 & 118 & 53.4 & 2,256 & 1,326 & 58.8 & 0.089 & 0.889 & 0.978 & $0.949 *$ \\
\hline Sales & 40 & 25 & 62.5 & 2,256 & 1,531 & 67.9 & 0.016 & 0.979 & 0.996 & 0.717 \\
\hline \multicolumn{11}{|c|}{ Appreciate / Depreciate } \\
\hline Purchases & 221 & 74 & 33.5 & 2,256 & 996 & 44.1 & 0.074 & 0.883 & 0.958 & $1.000 * * *$ \\
\hline Sales & 40 & 14 & 35.0 & 2,256 & 1,224 & 54.3 & 0.011 & 0.975 & 0.986 & $0.989 * *$ \\
\hline \multicolumn{11}{|c|}{ Leaning-against-the-wind } \\
\hline Purchases & 221 & 40 & 18.1 & 2,256 & 310 & 13.7 & 0.129 & 0.907 & 1.036 & $0.021 * *$ \\
\hline Sales & 40 & 11 & 27.5 & 2,256 & 291 & 12.9 & 0.038 & 0.985 & 1.023 & $0.003 * * *$ \\
\hline \multicolumn{11}{|c|}{ Panel H: Thailand } \\
\hline & \multicolumn{3}{|c|}{ Intervention } & \multicolumn{3}{|c|}{ Virtual } & \multirow{3}{*}{$\mathrm{p} 1$} & \multirow{3}{*}{$\mathrm{p} 2$} & \multirow{3}{*}{$\mathrm{p} 1+\mathrm{p} 2$} & \multirow{3}{*}{$1-\mathrm{CDF}$} \\
\hline & Total & Succe & esses & Total & Succes & sses & & & & \\
\hline & $\#$ & \# & $\%$ & $\#$ & \# & $\%$ & & & & \\
\hline \multicolumn{11}{|l|}{ General } \\
\hline Purchases & 93 & 62 & 66.7 & 2,308 & 1,450 & 62.8 & 0.043 & 0.964 & 1.007 & 0.187 \\
\hline Sales & 23 & 16 & 69.6 & 2,308 & 1,454 & 63.0 & 0.011 & 0.992 & 1.003 & 0.193 \\
\hline \multicolumn{11}{|c|}{ Appreciate / Depreciate } \\
\hline Purchases & 93 & 26 & 28.0 & 2,308 & 1,098 & 47.6 & 0.024 & 0.945 & 0.968 & $1.000 * * *$ \\
\hline Sales & 23 & 8 & 34.8 & 2,308 & 1,139 & 49.4 & 0.007 & 0.987 & 0.994 & 0.884 \\
\hline \multicolumn{11}{|c|}{ Leaning-against-the-wind } \\
\hline Purchases & 93 & 34 & 36.6 & 2,308 & 317 & 13.7 & 0.107 & 0.970 & 1.078 & $0.000 * * *$ \\
\hline Sales & 23 & 8 & 34.8 & 2,308 & 285 & 12.3 & 0.028 & 0.993 & 1.021 & $0.001 * * *$ \\
\hline
\end{tabular}


Table 3 Results of Asian Countries' Intervention Reaction Functions Using

\section{Firm News Category}

We estimate the intervention function using Heckman's (1979) two-step approach:

$Z_{t}^{*}=\hat{\mathrm{a}}_{0}+\mathrm{MOVAG}_{\mathrm{t}} \times \hat{\mathrm{a}}_{1}+\mathrm{SIG}_{\mathrm{t}} \times \hat{\mathrm{a}}_{2}+\mu_{t}$

$y_{t}=\hat{g}_{0}+\Delta S A M_{t} \times \hat{g}_{1}+\varepsilon_{t}$

Equation (9) is a probit model for the decision to intervene. MOVAG is the ten-day moving average of the 9:00 a.m. exchange rates. SIG is the ten-day rolling standard deviation of the 9:00 a.m. exchange rates in equation (10) that the number of intervention news. $\triangle S A M_{t}$ is the opening exchange rate of day $t$ minus the opening exchange rate of day $t-1$. The sample period is from January 2005 to November 2013. Figures in parentheses are t-statistics. ***, and $* * *$ denotes significance at the $90 \%, 95 \%$, and $99 \%$ confidence levels, respectively.

\begin{tabular}{ccccccccc}
\hline & India & $\begin{array}{c}\text { Indone } \\
\text { Sia }\end{array}$ & $\begin{array}{c}\text { Malays } \\
\text { ia }\end{array}$ & $\begin{array}{c}\text { Philippi } \\
\text { nes }\end{array}$ & $\begin{array}{c}\text { Singap } \\
\text { ore }\end{array}$ & $\begin{array}{c}\text { South } \\
\text { Korea }\end{array}$ & $\begin{array}{c}\text { Taiwa } \\
\text { n }\end{array}$ & $\begin{array}{c}\text { Thailan } \\
\text { d }\end{array}$ \\
\hline $\begin{array}{l}\text { Equatio } \\
\text { n (9) }\end{array}$ & & & & & & & & \\
MOVA & -0.10 & 0.01 & -2.06 & -1.08 & -4.08 & -0.18 & -0.01 & -0.09 \\
G & $(-7.21)^{*}$ & $(0.13)$ & $(-4.87)^{*}$ & $(-3.01)^{* *}$ & $(-5.35)^{*}$ & $(-2.56)$ & $(-0.55)$ & $(-5.13)^{*}$ \\
& $* *$ & & $* *$ & & $* *$ & $* *$ & & $* *$ \\
SIG & 1.84 & 1.21 & -1.85 & 1.27 & 4.69 & 1.02 & 3.14 & 0.08 \\
& $(7.54)^{*}$ & $(2.14)^{*}$ & $(-0.26)$ & $(2.71)^{* *}$ & $(2.49)^{*}$ & $(4.23)^{*}$ & $(6.54)^{*}$ & $(0.21)$ \\
& $* *$ & $*$ & & & $*$ & $* *$ & $* *$ & \\
CONS & 2.31 & 1.38 & 4.57 & -1.66 & 3.15 & 2.31 & 1.12 & 1.40 \\
& $(3.98)^{*}$ & $(3.79)^{*}$ & $(3.42)^{*}$ & $(3.55)^{* *}$ & $(3.20)^{*}$ & $(5.21)^{*}$ & $(1.50)$ & $(2.40)^{*}$ \\
& $* *$ & $* *$ & $* *$ & $*$ & $* *$ & $* *$ & & $*$ \\
Equatio & & & & & & & & \\
n (10) & & & & & & & & \\
$\Delta$ SAM & 0.14 & -0.01 & -0.25 & -0.32 & -2.94 & -0.11 & -0.49 & 0.34 \\
& $(0.57)$ & $(-0.09)$ & $(-0.04)$ & $(-0.02)$ & $(-2.87)^{*}$ & $(-1.61)$ & $(2.11)^{*}$ & $(0.81)$ \\
CONS & 2.33 & 1.08 & 1.67 & -0.07 & 1.42 & 1.33 & 1.15 & 1.50 \\
& $(4.81)$ & $(3.22)^{*}$ & $(2.58)^{*}$ & $(-1.37)$ & $(5.03)^{*}$ & $(3.05)^{*}$ & $(6.12)^{*}$ & $(2.93)^{*}$ \\
& $* * *$ & $* *$ & $*$ & & $* *$ & $* *$ & $* *$ & $*$ \\
Log & -473.21 & -632.60 & -202.15 & -419.63 & -197.17 & -678.33 & -902.43 & -542.93 \\
likeliho & & & & & & & & \\
od & & & & & & & & \\
\hline
\end{tabular}


Table 4 The Effects of Individual Variables on the Odds Ratio Using Firm News

\section{Category}

NEWSHAT is the number of reports after adjusting for sample selection bias. COUN is the number of countries jointly intervening on the same day. FIRS is a dummy variable that equals one when a firm report on intervention on day $t$ is the first intervention day in the past five business days. SUPP is a dummy variable that equals one when there is an official statement supporting interventions in Reuters' news reports. NEUT is a dummy variable that equals one when there is an official announcement of neutral reports. Announcement days refer to announcements on the repurchase rate (RR), interest rate (IR), interbank overnight rate (IOR), gross domestic product (GDP), consumer price index (CPI), balance of trade (BOT), and current account balance (CAB). The LR test is the likelihood ratio test for the null that all the coefficients of the covariates other than the intercept are equal to zero. The sample period is from January 2005 to November 2013. ***, and *** denotes significance at the $90 \%, 95 \%$, and $99 \%$ confidence levels, respectively. To conserve space, results for the macroeconomic announcements as control variables are not reported here.

\begin{tabular}{|c|c|c|c|c|c|c|}
\hline (A) India & Coefficient & t-statistic & & Intercept & t-statistic & LR test \\
\hline \multicolumn{7}{|c|}{ Intervention Variables } \\
\hline NEWSHAT & 6.511 & 7.580 & $k *$ & -13.455 & -9.810 & 58.960 \\
\hline COUN & 1.114 & 11.070 & $* *$ & -4.679 & -21.540 & 122.230 \\
\hline FIRS & 4.538 & 10.810 & $* *$ & -3.897 & -25.300 & 104.840 \\
\hline SUPP & 2.734 & 3.890 & $k *$ & -3.582 & -27.140 & 9.690 \\
\hline NEUT & 2.858 & 2.320 & $*$ & -3.551 & -27.340 & 3.440 \\
\hline \multicolumn{7}{|l|}{ (B) Indonesia } \\
\hline NEWSHAT & $4.76 \mathrm{e}-08$ & 4.550 & k* & -3.062 & -28.180 & 17.110 \\
\hline COUN & 1.057 & 13.130 & $* *$ & -3.777 & -26.280 & 178.390 \\
\hline FIRS & 3.385 & 12.620 & $* *$ & -3.175 & -29.510 & 136.370 \\
\hline SUPP & 1.959 & 5.100 & $k *$ & -2.914 & -30.700 & 18.970 \\
\hline NEUT & 1.765 & 2.620 & $* *$ & -2.864 & -31.020 & 4.970 \\
\hline (C) Malaysia & & $\sqrt{20}$ & & & & \\
\hline NEWSHAT & 17.157 & 4.090 & $k *$ & -25.625 & -4.820 & 30.270 \\
\hline COUN & 1.322 & 9.250 & $* *$ & -6.147 & -15.690 & 91.020 \\
\hline FIRS & 5.427 & 10.340 & $* *$ & -5.021 & -19.380 & 86.260 \\
\hline \multicolumn{7}{|c|}{ (D) Philippines } \\
\hline NEWSHAT & 0.048 & 0.190 & & -3.416 & -9.710 & 0.040 \\
\hline COUN & 1.374 & 13.110 & $* *$ & -4.888 & -21.590 & 209.700 \\
\hline FIRS & 5.023 & 15.090 & $k *$ & -4.119 & -24.520 & 241.830 \\
\hline SUPP & 2.709 & 4.340 & $* *$ & -3.403 & -28.790 & 12.550 \\
\hline \multicolumn{7}{|l|}{ (E) Singapore } \\
\hline NEWSHAT & 6.571 & 5.240 & $k *$ & -11.341 & -7.950 & 25.230 \\
\hline COUN & 1.358 & 9.770 & $* *$ & -6.058 & -16.190 & 106.600 \\
\hline FIRS & 6.245 & 12.100 & $* *$ & -5.329 & -17.630 & 155.990 \\
\hline \multicolumn{7}{|c|}{ (F) South Korea } \\
\hline NEWSHAT & $5.05 \mathrm{e}-03$ & 4.570 & $* * *$ & -3.109 & -28.610 & 16.640 \\
\hline COUN & 1.496 & 15.160 & $* * *$ & -4.494 & -23.550 & 311.010 \\
\hline FIRS & 3.586 & 12.240 & $* * *$ & -3.225 & -29.330 & 131.220 \\
\hline SUPP & 2.179 & 7.480 & $* * *$ & -3.063 & -29.940 & 41.28 \\
\hline NEUT & 1.464 & 2.260 & $* *$ & -2.930 & -30.750 & 3.760 \\
\hline \multicolumn{7}{|l|}{ (G) Taiwan } \\
\hline NEWSHAT & 9.209 & 4.220 & $* * *$ & -13.136 & -5.280 & 17.420 \\
\hline COUN & 1.063 & 13.480 & $* * *$ & -3.611 & -26.650 & 192.350 \\
\hline FIRS & 3.532 & 13.480 & $* * *$ & -3.057 & -29.580 & 168.610 \\
\hline SUPP & 2.647 & 5.660 & $* * *$ & -2.753 & -30.900 & 25.130 \\
\hline NEUT & 2.495 & 3.690 & $* * *$ & -2.719 & -31.040 & 10.440 \\
\hline \multicolumn{7}{|l|}{ (H) Thailand } \\
\hline \multirow[t]{2}{*}{ NEWSHAT } & 0.497 & 0.270 & & -3.993 & -1.680 & 0.070 \\
\hline & & 57 & & & & \\
\hline
\end{tabular}




\begin{tabular}{lcccccc} 
& ACCEPTED MIANUSCRIPT & & \\
COUN & 1.341 & 13.000 & $* * *$ & -4.830 & -21.800 & 201.490 \\
FIRS & 4.737 & 13.720 & $* * *$ & -3.918 & -25.740 & 187.650 \\
SUPP & 3.046 & 8.130 & $* * *$ & -3.525 & -28.010 & 46.270 \\
NEUT & 2.484 & 4.120 & $* * *$ & -3.401 & -28.780 & 11.200 \\
\hline
\end{tabular}


Table 5 Joint Significance of Variables on the Odds Ratio Using Firm News

\section{Category}

We use the logit regression to predict the success of central bank intervention:

$\hat{L}_{i}=\ln \left(\frac{\hat{P}_{i}}{1-\hat{P}_{i}}\right)=X_{i} \hat{b}+u_{i}$, where $X_{i}$ is a $(1 \times K)$ vector of variables, which include NEWSHAT, COUN, FIRS, SUPP, and NEUT. NEWSHAT is the number of reports after adjusting for sample selection bias. COUN is the number of countries jointly intervening on the same day. FIRS is a dummy variable that equals one when a firm report on intervention on day $t$ is the first intervention day in the past five business days. SUPP is a dummy variable that equals one when there is an official statement supporting interventions in Reuters' news reports. NEUT is a dummy variable that equals one when there is an official announcement of neutral reports. The LR test is the likelihood ratio test for the null that all the coefficients of the covariates other than the intercept are all equal to zero. LR test 1 is the likelihood ratio test statistic that compares the log likelihood function with only an intercept in the covariate to that of a regression that includes a constant and covariates. The term 'plus' implies that the variable is added to the existing list of regressors in the logit regression. LR test2 is the likelihood ratio test statistic for the null that the benchmark regression contains the covariates in the same row as '-'. The sample period is from January 2005 to November 2013. ***, and *** denote significance at the $90 \%, 95 \%$, and $99 \%$ confidence levels, respectively.

\begin{tabular}{|c|c|c|c|}
\hline \multicolumn{4}{|c|}{ Panel A: India } \\
\hline & Log Likelihood & LR test 1 & LR test 2 \\
\hline (1) NEWSHAT & -252.60 & $58.96 * * *$ & - \\
\hline plus COUN & -207.47 & $149.23 * * *$ & $90.27 * * *$ \\
\hline plus FIRS & -206.31 & $151.55 * * *$ & $92.59 * * *$ \\
\hline plus SUPP & -249.10 & $65.97 * * *$ & $7.01 *$ \\
\hline plus NEUT & -251.44 & $61.30 * * *$ & 2.33 \\
\hline (2) NEWSHAT, FIRS & -206.31 & $151.55 * * *$ & - \\
\hline plus COUN & -175.83 & $212.52 * * *$ & $60.97 * * *$ \\
\hline plus SUPP & -201.83 & $160.51 * * *$ & $8.96 * *$ \\
\hline plus NEUT & -204.82 & $154.53 * * *$ & $2.97 *$ \\
\hline (3) NEWSHAT, FIRS, COUN & -175.83 & $212.52 * * *$ & - \\
\hline plus SUPP & -170.90 & $222.38 * * *$ & $9.86 * * *$ \\
\hline plus NEUT & -175.37 & $213.43 * * *$ & 0.9 \\
\hline (4) NEWSHAT, FIRS, SUPP & -170.90 & $222.38 * * *$ & - \\
\hline plus NEUT & -170.41 & $223.35 * * *$ & 0.98 \\
\hline \multicolumn{4}{|c|}{ Panel B: Indonesia } \\
\hline & Log Likelihood & LR test 1 & LR test 2 \\
\hline (1) FIRS & -423.66 & $136.37 * * *$ & - \\
\hline plus NEWSHAT & -413.82 & $156.05 * * *$ & $19.68 * * *$ \\
\hline plus COUN & -366.65 & $250.39 * * *$ & $114.02 * * *$ \\
\hline plus SUPP & -416.68 & $150.34 * * *$ & $13.97 * * *$ \\
\hline plus NEUT & -420.36 & $142.98 * * *$ & $6.61 * *$ \\
\hline plus IR & -422.25 & $139.19 * * *$ & $2.83 *$ \\
\hline (2) FIRS, COUN & -366.65 & $250.39 * * *$ & - \\
\hline plus NEWSHAT & -360.84 & $262.02 * * *$ & $11.63 * * *$ \\
\hline plus SUPP & -363.42 & $256.85 * * *$ & $6.46 * *$ \\
\hline plus NEUT & -365.54 & $252.62 * * *$ & 2.23 \\
\hline plus IR & -365.38 & $252.94 * * *$ & 2.55 \\
\hline (3) FIRS, COUN, NEWSHAT & -360.84 & $262.02 * * *$ & - \\
\hline plus SUPP & -357.86 & $267.98 * * *$ & $5.96 * *$ \\
\hline plus NEUT & -360.34 & $263.01 * * *$ & 0.99 \\
\hline
\end{tabular}




\begin{tabular}{|c|c|c|c|}
\hline \multicolumn{4}{|c|}{ ACCEPTED MANUSCRIPT } \\
\hline plus IR & -359.42 & $264.86 * * *$ & $0.99 *$ \\
\hline (4) FIRS, COUN, NEWSHAT & -357.86 & $267.98 * * *$ & - \\
\hline plus NEUT & -357.28113 & $269.13 * * *$ & 1.15 \\
\hline plus IR & -356.63726 & $270.42 * * *$ & 2.44 \\
\hline \multicolumn{4}{|c|}{ Panel C: Malaysia } \\
\hline & Log Likelihood & LR test 1 & LR test2 \\
\hline (1) NEWSHAT & -131.82 & $30.27 * * *$ & - \\
\hline plus COUN & -92.29 & $109.33 * * *$ & $79.07 * * *$ \\
\hline plus FIRS & -95.89 & $102.13 * * *$ & $71.86 * * *$ \\
\hline (2) NEWSHAT, COUN & -92.29 & $109.33 * * *$ & - \\
\hline plus FIRS & -74.30 & $145.31 * * *$ & $35.98 * * *$ \\
\hline (3) NEWSHAT, COUN, FIRS & -74.30 & $145.31 * * *$ & - \\
\hline
\end{tabular}

\begin{tabular}{lrrc}
\hline & Panel D: Philippines & & \\
\hline \hline & Log Likelihood & LR test1 & LR test 2 \\
\hline (1) FIRS & -220.00 & $241.83 * * *$ & - \\
plus NEWSHAT & -219.62 & $242.61 * * *$ & 0.77 \\
plus COUN & -169.08 & $343.69 * * *$ & $101.86 * * *$ \\
plus SUPP & -217.97 & $245.91 * * *$ & $4.08 * *$ \\
(2) FIRS, COUN & -169.08 & $343.69 * * *$ & - \\
plus NEWSHAT & -167.59 & $346.67 * * *$ & $2.98 *$ \\
plus SUPP & -168.55 & $344.74 * * *$ & 1.05 \\
(3) FIRS, COUN, NEWSHAT & -167.59 & $346.67 * * *$ & - \\
plus SUPP & -167.17 & $347.51 * * *$ & 0.84 \\
\hline & & & \\
\hline \hline & Panel E: Singapore & & LR test2 \\
\hline (1) NEWSHAT & Log Likelihood & LR test1 & - \\
plus COUN & 6.57 & $25.23 * * *$ & \\
plus FIRS & -101.29 & $126.21 * * *$ & $100.97 * * *$ \\
(2) NEWSHAT, FIRS & -78.71 & $171.37 * * *$ & $146.14 * * *$ \\
plus COUN & -78.71 & $171.37 * * *$ & - \\
(3) NEWSHAT, FIRS, COUN & -54.41 & $219.96 * * *$ & $48.60 * * *$ \\
\hline
\end{tabular}

\begin{tabular}{lrrc}
\hline \multicolumn{4}{c}{ Panel F: South Korea } \\
& Log Likelihood & LR test1 & LR test2 \\
\hline \hline (1) FIRS & -402.95 & $131.22 * * *$ & - \\
plus NEWSHAT & -395.46 & $146.19 * * *$ & $14.98 * * *$ \\
plus COUN & -284.41 & $368.29 * * *$ & $237.08 * * *$ \\
plus SUPP & -392.58 & $151.95 * * *$ & $20.73 * * *$ \\
plus NEUT & -402.73 & $131.66 * * *$ & 0.44 \\
(2) FIRS, COUN & -284.41 & $368.29 * * *$ & - \\
plus NEWSHAT & -282.04 & $373.02 * * *$ & $4.73 * *$ \\
plus SUPP & -282.01 & $373.09 * * *$ & $4.79 * *$ \\
plus NEUT & -284.33 & $368.45 * * *$ & 0.15 \\
(3) FIRS, COUN, SUPP & -282.01 & $373.09 * * *$ & - \\
plus NEWSHAT & -279.48 & $378.15 * * *$ & $5.06 * *$ \\
plus NEUT & -281.95 & $373.22 * * *$ & 0.13 \\
(4) FIRS, COUN, SUPP, NEWSHAT & -279.48 & $378.15 * * *$ & - \\
plus NEUT & -279.46 & $378.19 * * *$ & 0.04 \\
\hline
\end{tabular}




\section{Panel G: Taiwan}

\begin{tabular}{|c|c|c|c|}
\hline & Log Likelihood & LR test 1 & LR test 2 \\
\hline (1) NEWSHAT & -524.06 & $17.42 * * *$ & - \\
\hline plus COUN & -425.02 & $215.50 * * *$ & $198.08 * * *$ \\
\hline plus FIRS & -439.81 & $185.91 * * *$ & $168.49 * * *$ \\
\hline plus SUPP & -513.47 & $38.60 * * *$ & $21.18 * * *$ \\
\hline plus NEUT & -519.08 & $27.39 * * *$ & $9.97 * * *$ \\
\hline (2) NEWSHAT, COUN & -425.02 & $215.50 * * *$ & - \\
\hline plus FIRS & -371.13 & $323.28 * * *$ & $107.78 * * *$ \\
\hline plus SUPP & -418.22 & $229.10 * * *$ & $13.60 * * *$ \\
\hline plus NEUT & -423.77 & $217.99 * * *$ & 2.49 \\
\hline (3) NEWSHAT, COUN, FIRS & -371.13 & $323.28 * * *$ & - \\
\hline plus SUPP & -364.16 & $337.22 * * *$ & $13.94 * * *$ \\
\hline plus NEUT & -370.47 & $324.60 * * *$ & 1.32 \\
\hline (4) NEWSHAT, COUN, FIRS, SUPP & -364.16 & $337.22 * * *$ & - \\
\hline \multirow[t]{3}{*}{ plus NEUT } & -363.41 & $338.71 * * *$ & 1.49 \\
\hline & \multicolumn{3}{|l|}{ Panel H: Thailand } \\
\hline & \multicolumn{2}{|c|}{ Log Likelihood LR test1 } & LR test2 \\
\hline (1) FIRS & -247.02 & $187.65 * * *$ & - \\
\hline plus NEWSHAT & -247.01 & $187.68 * * *$ & 0.02 \\
\hline plus COUN & -189.63 & $302.44 * * *$ & $114.79 * * *$ \\
\hline plus SUPP & -238.44 & $204.82 * * *$ & $17.16 * * *$ \\
\hline plus NEUT & -241.60 & $198.50 * * *$ & $10.84 * * *$ \\
\hline (2) FIRS, COUN & -189.63 & $302.44 * * *$ & - \\
\hline plus NEWSHAT & -187.48 & $306.75 * * *$ & $4.31 * *$ \\
\hline plus SUPP & -184.98 & $311.75 * * *$ & $9.31 * * *$ \\
\hline plus NEUT & -184.99 & $311.72 * * *$ & $9.28 * * *$ \\
\hline (3) FIRS, COUN, SUPP & -184.98 & $311.75 * * *$ & - \\
\hline plus NEWSHAT & -182.78 & $316.14 * * *$ & $4.39 * *$ \\
\hline plus NEUT & -179.98 & $321.74 * * *$ & $9.99 * * *$ \\
\hline (4) FIRS, COUN, SUPP, NEUT & -179.98 & $321.74 * * *$ & - \\
\hline plus NEWSHAT & -178.01 & $325.68 * * *$ & $3.94 * *$ \\
\hline
\end{tabular}




\section{Appendix}

\section{Table A1 Sample News Reports}

We classify news reports into four categories: firm, suspected, support, and neutral. The firm news category refers to news that clearly indicate that the central bank intervened in currency markets. The suspected news category is for news that cast doubt on official foreign exchange intervention. The supported news category is for news that indicate that central bank or government officials provided a statement of support for intervention in the foreign exchange market. The neutral news category is for news that indicates central bankers or government officials provided a neutral opinion on foreign exchange intervention activities. The column heading of 'Actions' represents buying or selling of US dollars, or no clear intervention strategy. The examples of news content are obtained from Indonesia' $s$ reports.

\begin{tabular}{|c|c|c|}
\hline Category & Action & Examples \\
\hline \multirow{3}{*}{ Firm } & Buy & $\begin{array}{l}\text { The central bank was spotted buying dollars, initially from } 8,600 \text { up to } \\
8,610 \text {, but pulled back its intervention lines. }\end{array}$ \\
\hline & or & $\begin{array}{l}\text { It is stuck because the central bank keeps intervening to support } \\
\text { USD/IDR, so it doesn't break the } 8,705 \text { level. }\end{array}$ \\
\hline & Sell & $\begin{array}{l}\text { The central bank was spotted selling dollars to check the rupiah's decline, } \\
\text { dealers said. }\end{array}$ \\
\hline \multirow{3}{*}{ Suspected } & Buy & $\begin{array}{l}\text { Traders said they suspected authorities were intervening to buy dollars } \\
\text { on Thursday at levels around } 9,288 \text { to } 9,290 \text { to smooth currency } \\
\text { volatility. }\end{array}$ \\
\hline & or & Traders suspect Bank Indonesia intervened again to curb rupiah strength. \\
\hline & Sell & $\begin{array}{l}\text { The Indonesian rupiah hovered near } 9,870-9,880 \text { per dollar as the central } \\
\text { bank was suspectedly selling dollars in the market to prop up the } \\
\text { weakening currency, traders said. }\end{array}$ \\
\hline \multirow{3}{*}{ Supported } & \multirow{3}{*}{ No } & $\begin{array}{l}\text { "We have already studied it very carefully, knowing which are the } \\
\text { aggressive players. We know the players," Nasution said, adding "BI is } \\
\text { in the market to prevent excessive volatility in the market."--Bank } \\
\text { Indonesia's (BI) senior deputy governor, Darmin Nasution }\end{array}$ \\
\hline & & $\begin{array}{l}\text { Central bank governor Boediono said the bank will remain in the market } \\
\text { to support the rupiah. }\end{array}$ \\
\hline & & $\begin{array}{l}\text { Indonesia's central bank will not let the rupiah hit "irrational" levels, } \\
\text { Bank Indonesia's governor said on Tuesday, following a further } \\
\text { depreciation of the currency. }\end{array}$ \\
\hline \multirow{3}{*}{ Neutral } & \multirow{3}{*}{ No } & $\begin{array}{l}\text { Budi Mulya, a deputy governor of Bank Indonesia (BI), told Reuters that } \\
\text { the central bank would not curb strengthening in the rupiah as it reflects } \\
\text { investor optimism on the country's economic fundamentals. }\end{array}$ \\
\hline & & $\begin{array}{l}\text { The rupiah rebounded to } 10,800 \text { per dollar to be virtually unchanged } \\
\text { from Monday's close after President Susilo Bambang Yudhoyono said } \\
\text { authorities may announce a new policy response to the currency's fall. } \\
\text { He didn' t provide any details. }\end{array}$ \\
\hline & & $\begin{array}{l}\text { The rupiah was "still within fundamental range" despite its recent gains, } \\
\text { said acting central bank Governor Darmin Nasution. }\end{array}$ \\
\hline
\end{tabular}


Highlights

1. We test the odds of intervention success by Asian central banks in FX market.

2. Results show that leaning-against-the-wind intervention strategies are effective.

3. Joint and first day interventions also increase the odds of intervention success. 